\title{
Safety and efficacy outcomes of first and second generation durable polymer drug eluting stents and biodegradable polymer biolimus eluting stents in clinical practice: comprehensive network meta-analysis
}

\author{
(c) $\frac{(1)(8)}{\mathrm{gy}}$ MPEN ACCESS
}

Eliano P Navarese assistant professor of medicine and director of research ${ }^{1}$, Kenneth Tandjung resident $^{2}$, Bimmer Claessen resident ${ }^{3}$, Felicita Andreotti aggregate professor of medicine ${ }^{4}$, Mariusz Kowalewski research fellow ${ }^{1}$, David E Kandzari professor of medicine ${ }^{5}$, Dean J Kereiakes professor of medicine ${ }^{6}$, Ron Waksman professor of medicine ${ }^{7}$, Laura Mauri professor of medicine ${ }^{8}$, Ian T Meredith professor of medicine ${ }^{9}$, Aloke V Finn assistant professor of medicine ${ }^{10}$, Hyo-Soo Kim professor of medicine ${ }^{11}$, Jacek Kubica professor of medicine ${ }^{1}$, Harry Suryapranata professor of medicine $^{12}$, Toni Mustahsani Aprami profesor of medicine ${ }^{13}$, Giuseppe Di Pasquale cardiologist ${ }^{14}$, Clemens von Birgelen professor of medicine ${ }^{215}$, Elvin Kedhi interventional cardiologist ${ }^{16}$

\footnotetext{
${ }^{1}$ Department of Cardiology and Internal Medicine, Ludwik Rydygier Collegium Medicum, Nicolaus Copernicus University, Bydgoszcz, Poland; ${ }^{2}$ Department of Cardiology, Thoraxcentrum Twente, Medisch Spectrum Twente, Enschede, Netherlands; ${ }^{3}$ Department of Cardiology, Academisch Medisch Centrum, Universiteit van Amsterdam, Netherlands; ${ }^{4}$ Department of Cardiovascular Science, Catholic University, Rome, Italy; ${ }^{5}$ Piedmont Heart Institute, Atlanta, GA, USA; ${ }^{6}$ Department of Cardiology, Christ Hospital Heart and Vascular Center/Lindner Research Center, Cincinnati, OH, USA; ${ }^{7}$ Division of Cardiology, MedStar Washington Hospital Center, Washington DC, USA; ${ }^{8}$ Department of Cardiology, Brigham and Women's Hospital, Harvard Medical School, Boston, MA, USA; ${ }^{9}$ Department of Cardiology, MonashHeart, Monash Medical Centre and Monash University, Melbourne, Australia; ${ }^{10}$ Department of Cardiology, Emory University School of Medicine, Atlanta, USA; ${ }^{11}$ Division of Cardiology, Department of Internal Medicine, Seoul National University College of Medicine, Seoul, Republic of Korea; ${ }^{12}$ Department of Cardiology, UMC St Radboud, Nijmegen, Netherlands; ${ }^{13}$ Department of Cardiology, Padjadjaran University Hospital Hasan Sadikin, Bandung, Indonesia; ${ }^{14}$ Unità Ospedaliera di Cardiologia, Ospedale Maggiore, Bologna, Italy; ${ }^{15} \mathrm{Health}$ Technology and Services Research, MIRA-Institute for Biomedical Technology and Technical Medicine, University of Twente, Enschede, Netherlands; ${ }^{16}$ Department of Cardiology, Isala Klinieken, 8025 AB Zwolle, Netherlands
}

\begin{abstract}
Objectives To investigate the safety and efficacy of durable polymer drug eluting stents (DES) and biodegradable polymer biolimus eluting stents (biolimus-ES).

Design Network meta-analysis of randomised controlled trials.

Data sources and study selection Medline, Google Scholar, Embase, and Cochrane Central Register of Controlled Trials (CENTRAL) database search for randomised controlled trials comparing at least two of durable polymer sirolimus eluting stents (sirolimus-ES) and paclitaxel eluting stents (paclitaxel-ES), newer durable polymer everolimus eluting stents (everolimus-ES), Endeavor and Resolute zotarolimus eluting stents (zotarolimus-ES), and biodegradable polymer biolimus-ES.
\end{abstract}

Primary outcomes Safety (death, myocardial infarction, definite or probable stent thrombosis) and efficacy (target lesion and target vessel revascularisation) assessed at up to one year and beyond.

Results 60 randomised controlled trials were compared involving 63 242 patients with stable coronary artery disease or acute coronary syndrome treated with a DES. At one year, there were no differences in mortality among devices. Resolute and Endeavor zotarolimus-ES, everolimus-ES, and sirolimus-ES, but not biodegradable polymer biolimus-ES, were associated with significantly reduced odds of myocardial infarction (by 29-34\%) compared with paclitaxel-ES. Compared with everolimus-ES, biodegradable polymer biolimus-ES were associated with significantly increased odds of myocardial infarction (by $29 \%$ ), while Endeavor zotarolimus-ES and paclitaxel-ES were 
associated with significantly increased odds of stent thrombosis. All investigated DES were similar with regards to efficacy endpoints, except for Endeavor zotarolimus-ES and paclitaxel-ES, which were associated with significantly increased the odds of target lesion and target vessel revascularisations compared with other devices. Direction of results beyond one year did not diverge from the findings for up to one year follow-up. Bayesian probability curves showed a gradient in the magnitude of effect, with everolimus-ES and Resolute zotarolimus-ES offering the highest safety profiles.

Conclusions The newer durable polymer everolimus-ES and Resolute zotarolimus-ES and the biodegradable polymer biolimus-ES maintain the efficacy of sirolimus-ES; however, for safety endpoints, differences become apparent, with everolimus-ES and Resolute zotarolimus-ES emerging as the safest stents to date.

\section{Introduction}

The first generation of coronary drug eluting stents (DES) has considerably reduced the need for repeat revascularisation compared with bare metal stents (BMS) and has led to their widespread use worldwide. Concerns have emerged, however, regarding late and very late thrombotic events, which in turn are associated with a high rate of death and myocardial infarction. ${ }^{12}$ Such events have been attributed to incomplete re-endothelialisation caused by drug induced inhibition of endothelial cell proliferation, stent malapposition, accelerated neoatherosclerosis, and, importantly, polymer induced prolonged vessel wall inflammation. ${ }^{3}$

To improve the safety of first generation DES, new devices have been developed that use either biocompatible durable polymers combined with new metal alloys or biodegradable polymers combined with stainless steel platforms; both have been extensively tested in randomised controlled trials. The second generation durable polymer everolimus eluting stent (everolimus-ES) has been found to be safer than BMS and first generation DES. ${ }^{4-6}$ On the other hand, two non-inferiority trials comparing the most investigated biodegradable polymer device, the biolimus eluting stent (biolimus-ES), with the first generation sirolimus eluting stent (sirolimus-ES) have provided contradictory results at one year, ${ }^{78}$ with one trial showing non-inferiority and the other failing to do so. Two other trials have shown non-inferiority of biodegradable polymer biolimus-ES compared with everolimus-ES. ${ }^{9}{ }^{10}$ None of these trials was powered for separate safety and efficacy endpoints.

In light of these findings, the safety and efficacy of the biodegradable polymer devices compared with first generation paclitaxel-eluting stents (paclitaxel-ES) and sirolimus-ES, and with second generation durable polymer Endeavor and Resolute zotarolimus eluting stents (zotarolimus-ES) and everolimus-ES, are currently unclear. We performed a comprehensive network meta-analysis of all relevant data published and presented to date to gain an evidence based understanding of the impact of each of these devices compared with first generation DES and among each other on major safety and efficacy outcomes.

\section{Methods}

\section{Study design and endpoint selection}

We compared the safety and efficacy of DES currently approved by the Food and Drug Administration (FDA) - that is, first and second generation durable polymer DES and biodegradable polymer biolimus-ES. We selected biodegradable polymer biolimus-ES from among the different types of biodegradable polymer stents for two reasons: they have the most robust trial data, and all available biodegradable polymer biolimus-ES prototypes share a stainless steel platform, similar strut thickness, and the same abluminal biodegradable polymer (poly-L-lactic acid) and therefore are generally considered equivalent. We limited our analysis to biodegradable polymer biolimus-ES as the other non-FDA approved biodegradable polymer devices are characterised by a limited number or absence of comparisons and by different stent designs (in terms of strut thickness, antiproliferative agents, and polymers), resulting in a large degree of heterogeneity among existing devices. Because of the conflicting one year outcome results, our primary pre-specified analyses were for up to one year follow-up, though we also analysed longer follow-ups. To provide the most robust evidence, we included randomised controlled trials enrolling at least 100 patients and with a minimum follow-up of six months.

To appreciate the comparative effect of different types of DES within their class, we did not include BMS. We included first generation durable polymer sirolimus-ES and paclitaxel-ES; second generation durable polymer everolimus-ES, Endeavor zotarolimus-ES, and Resolute zotarolimus-ES; and biodegradable polymer biolimus-ES. Prespecified safety endpoints comprised overall mortality, myocardial infarction, and definite or probable stent thrombosis according to the definition criteria of the Academic Research Consortium. ${ }^{11}$ Efficacy endpoints were target lesion and target vessel revascularisation.

Although there were a limited number of trials comparing biodegradable polymer biolimus-ES with first and second generation DES that reported results beyond one year, we additionally performed such an analysis (see appendix).

\section{Data source and search strategy}

We adhered to the PRISMA (Preferred Reporting Items for Systematic reviews and Meta-Analyses) statement for reporting systematic reviews and meta-analyses in healthcare interventions. ${ }^{12}$ Medline, Cochrane Central Register of Controlled Trials (CENTRAL), Google Scholar, and Embase databases and www.tctmd.com, www.clinicaltrials.gov, www. clinicaltrialresults.org, and www.cardiosource.com websites were searched until 15 May 2013 for relevant randomised controlled trials; documents accessible through the FDA website were also scrutinised. The following keywords were used: "randomised trials", "drug-eluting stent", "sirolimus stent", "paclitaxel stent", "everolimus stent", "zotarolimus stent", "Endeavor zotarolimus-stent", "Resolute zotarolimus-stent", "biodegradable polymer stent", "bioabsorbable polymer stent", "biolimus stent". No language, date, or publication status restrictions were imposed. For each trial, we used the most updated or most inclusive data.

\section{Data collection and quality assessment}

Four investigators (EPN, KT, BC, MK) critically and independently evaluated identified trials with regard to patient population, treatment, protocol, and endpoint selection. Divergences were resolved by consensus. Two investigators (BC, KT) independently appraised the potential risk of bias in trials according to the Cochrane Collaboration guidelines (adequate sequence generation, allocation concealment, blinded adjudication of events) ${ }^{12}$; discrepancies were resolved by discussion with a third investigator (EPN). EK supervised the data collection process. Trials with high or unclear risk of bias for any of these components were regarded as trials with a high risk of bias. 


\section{Statistical analyses}

We used network meta-analysis methods on all available treatment comparisons to provide the most comprehensive evidence, incorporating direct comparisons within trials between two treatments (such as A $v$ B) and indirect comparisons from trials having one treatment in common (such as $\mathrm{A} v \mathrm{C}$ using trials comparing $\mathrm{A} v \mathrm{~B}$ and $\mathrm{B} v \mathrm{C}) .{ }^{13}$ Outcome analyses were compared by odds ratios and $95 \%$ credible intervals with a bayesian hierarchical random effects model that takes into account multi-arm trials. We adopted the random effects rather than the fixed effects model as the most appropriate and conservative analysis to account for differences among trials. Additional sensitivity analyses were conducted by repeating the main computations with the fixed effect method and by excluding trials with high risk of bias.

To further corroborate the robustness of the data and make probability inferences, we generated bayesian probability curves for each stent with sirolimus-ES as reference; rather than focusing on a single probability value, these curves provide a ranking of competing stent treatments with respect to overall safety and efficacy. Median rates of safety and efficacy outcomes, with corresponding credible intervals, were also calculated from the original trials in the network meta-analysis.

Heterogeneity was defined as the variability of results across trials over and above chance, with $\tau^{2}<0.04$ indicating low level and $\tau^{2}>0.4$ a high level. Potential inconsistency of the network, defined as the variability of results across the direct and indirect evidence comparisons, was evaluated by the node split method and the relative bayesian $P$ value, measuring agreement between direct and indirect evidence for each split node. ${ }^{14}$ Inconsistency was additionally evaluated by inspection of the goodness of fit of the model to the data with residual deviance; the model was considered to provide an adequate fit when the mean of the residual deviance was similar to the number of data points of the model.

For outcomes beyond one year, given the variable length of follow-up for each of these trials, we used the rate of outcome per 100 patient years to obtain the log rate ratios of one stent compared with another. Rates per unit of time, rather than number of events, were deemed the most appropriate outcome measure for long term analyses as they incorporate the duration of the trials, which was variable. A Poisson regression model was fitted because this analysis explicitly exploits differences in follow-up among studies, thus maximising precision. ${ }^{15} \mathrm{We}$ assessed the extent of small study effects/publication bias by visual inspection of funnel plots. All analyses were based on non-informative previous findings for effect sizes and precision, which yield results that are comparable with those obtained from conventional statistical analyses. Convergence and lack of autocorrelation were checked and confirmed. In the bayesian framework, we regarded as significant results for which the credible intervals of the odds ratios or rate ratios did not include the unit value. Data were analysed according to the intention to treat principle. All analyses were conducted with WinBUGS 1.4.3 (MRC Biostatistics Unit, Cambridge, UK) and MIX 2.0. Pro for Microsoft Excel, version 2.0.1.2, (BiostatXL, California, USA).

\section{Results}

\section{Study selection and patient population}

The flow diagram of the analysis, the full electronic Medline database search, and the inclusion/exclusion criteria and risk of bias of the included randomised controlled trials are shown in the appendix (fig S1, table S1, table S2). Sixty trials, ${ }^{7-10} 16-88$ comprising 63242 randomised patients, met the inclusion criteria and entered the final analysis. Table 1 shows information on stent comparators, duration of follow-up, and investigated populations $\Downarrow$. In general, the included populations were high risk groups, with most trials enrolling patients with stable coronary artery disease $(53.7 \%)$ and acute coronary syndromes $(46.3 \%)$. Nearly all included trials were multicentre, with a low risk of bias. We excluded trials testing two stents eluting the same drug but differing in their design, ${ }^{89-91}$ trials with different stent metal platforms, ${ }^{92-96}$ post hoc analyses or substudies, ${ }^{97-103}$ the BMS arm or polymer free arm of six trials with three arms, ${ }^{16} 17383954104$ studies that did not report clinical outcomes, ${ }^{105}$ and arms that did not include treatments in the network. Figure 1 shows the evidence network of direct comparisons $\Downarrow$.

\section{One year outcomes Safety profile}

A total of 46 studies ( $n=48908$ ) contributed to the analysis of one year mortality. Second generation durable polymer DES and biodegradable polymer biolimus-ES were associated with mortality outcomes that did not differ significantly from those of paclitaxel-ES and sirolimus-ES (fig $2 \Downarrow$ ), although median one year rates varied almost twofold, ranging from $1.80 \%$ to $3.05 \%$ (numerical gradient: Resolute zotarolimus-ES < everolimus-ES $<$ sirolimus-ES $<$ biodegradable polymer biolimus-ES < paclitaxel-ES < Endeavor zotarolimus-ES) (table $2 \Downarrow)$.

Forty six studies ( $\mathrm{n}=51578)$ contributed to the analysis of myocardial infarction by one year. Compared with paclitaxel-ES, all DES except biodegradable polymer biolimus-ES significantly reduced the odds of myocardial infarction, particularly Resolute zotarolimus-ES and everolimus-ES (odds ratio 0.66 (95\% credible interval 0.46 to 0.91 ) and 0.67 (0.53 to 0.81 ), respectively) (fig $3 \Downarrow$ ). Compared with sirolimus-ES, the odds of myocardial infarction were not significantly reduced by second generation DES, although everolimus-ES and Resolute zotarolimus-ES, unlike biodegradable polymer biolimus-ES, showed numerical reductions (fig $3 \Downarrow$ ). When new generation DES were compared among each other, biodegradable polymer biolimus-ES yielded a significant increase in the odds of myocardial infarction $(1.29,1.02$ to 1.69$)$ compared with everolimus-ES. Lowest median rates of myocardial infarction were observed with Resolute zotarolimus-ES and everolimus-ES (table $2 \Downarrow$ ). There was no evidence of high heterogeneity among trials for either death $\left(\tau^{2}=0.007\right)$ or myocardial infarction $\left(\tau^{2}=0.008\right)$ outcomes (supplementary table S3).

Compared with paclitaxel-ES and Endeavor zotarolimus-ES, median rates of stent thrombosis were approximately halved with everolimus-ES, Resolute zotarolimus-ES, biodegradable polymer biolimus-ES, and sirolimus-ES ( 1\% v 2.5\%) (table $2 \Downarrow)$. Everolimus-ES provided significant reductions of the odds of stent thrombosis at one year compared with paclitaxel-ES $(0.37,0.18$ to 0.65$)$ and a numerical reduction compared with sirolimus-ES $(0.63,0.33$ to 1.06 ) (fig $4 \Downarrow$ ); compared with everolimus-ES, Endeavor zotarolimus-ES yielded a significant increase in the odds of stent thrombosis (3.13, 1.15 to 8.89). There was no evidence of high heterogeneity among trials for stent thrombosis $\left(\tau^{2}=0.21\right.$; appendix table $\left.\mathrm{S} 3\right)$.

\section{Efficacy profile}

Forty four trials including 49527 patients contributed to the analysis of target lesion revascularisation at one year. Sirolimus-ES, everolimus-ES, biodegradable polymer 
biolimus-ES, and Resolute zotarolimus-ES significantly reduced the odds of target lesion revascularisation by $46 \%$ to $87 \%$ compared with paclitaxel-ES, and by $59 \%$ to $160 \%$ compared with Endeavor zotarolimus-ES (fig $5 \Downarrow$ ). Compared with sirolimus-ES, the same devices (everolimus-ES, Resolute zotarolimus-ES, and biodegradable polymer biolimus-ES) showed a similar degree of efficacy, without significant differences between them (fig 5). The median target lesion revascularisation rate was $\sim 3 \%$ with everolimus-ES, biodegradable polymer biolimus-ES, sirolimus-ES, and Resolute zotarolimus-ES versus $5.92 \%$ with paclitaxel-ES and $7.52 \%$ with Endeavor zotarolimus-ES (table 2). $\Downarrow$

Target vessel revascularisation results at one year were consistent with target lesion revascularisation outcomes. Compared with sirolimus-ES, everolimus-ES, Resolute zotarolimus-ES, and biodegradable polymer biolimus-ES provided similar efficacy profiles, whereas Endeavor zotarolimus-ES and paclitaxel-ES were associated with higher odds of target vessel revascularisation (odds ratio 1.67 (95\% credible interval 1.08 to 2.58 ) and 1.47 (1.14 to 1.90 ), respectively) (fig $6 \Downarrow$ ). There was no evidence of high heterogeneity among trials for both target lesion revascularisation $\left(\tau^{2}=0.13\right)$ and target vessel revascularisation $\left(\tau^{2}=0.12\right)$ outcomes (appendix table $\left.S 3\right)$.

\section{Posterior probabilities}

Figure $7 \Downarrow$ shows the posterior probability curves for each DES and for each outcome, with sirolimus-ES as reference treatment. These curves allow probability inferences associated with a specific threshold of risk (odds ratio). Thus, compared with sirolimus-ES, the curves show a probability of $65 \%$ for Resolute zotarolimus-ES to reduce the odds of mortality by at least $20 \%$ (odds ratio 0.80 ); a probability of $56 \%$ and $49 \%$ for Resolute zotarolimus-ES and everolimus-ES, respectively, to reduce the odds of myocardial infarction by at least $10 \%(0.90)$; and a probability of $81 \%$ with everolimus-ES and $51 \%$ with Resolute zotarolimus-ES to reduce the odds of stent thrombosis by at least $20 \%$.

Compared with sirolimus-ES, Resolute zotarolimus-ES showed a $30 \%$ probability to reduce target vessel revascularisation and a $21 \%$ probability to reduce target lesion revascularisation by at least $20 \%$ (odds ratio 0.80 ), which was comparable with the $17 \%$ probability seen with everolimus-ES and biodegradable polymer biolimus-ES.

\section{Outcomes beyond one year}

Twenty four trials $(n=38097)$ contributed to the analysis of follow-up after one year (table 1) $\Downarrow$. As with the one year mortality results, long term mortality with first and second generation durable polymer DES and with biodegradable polymer biolimus-ES did not differ significantly among the different DES (appendix table S4).

As seen with the one year outcomes, in comparison with paclitaxel-ES, Endeavor zotarolimus-ES, everolimus-ES, and Resolute zotarolimus-ES (similarly to sirolimus-ES) provided a $31-37 \%$ significant decrease in myocardial infarction. Everolimus-ES was associated with a significant $56 \%$ reduction of the rate of definite or probable stent thrombosis against first generation sirolimus-ES. Again, similar to the one year outcomes, compared with first generation paclitaxel-ES, newer generation DES offered significantly lower rates of revascularisation, except for Endeavor zotarolimus-ES, which was associated with a $110 \%$ increase compared with everolimus-ES (appendix table S4).

\section{Overall fit of the model and additional analyses}

Evaluation of the goodness of fit for the models showed adequate fit for the various analyses. Heterogeneity among the trials was low to moderate for all outcomes (appendix table S3). Sensitivity analyses based on the fixed effect model did not significantly change the results of the meta-analysis (appendix table S5). Visual inspection of funnel plots did not suggest any small study effects or publication bias (appendix figs S2A-D). Exclusion of trials with high risk of bias (appendix table S6) yielded results largely consistent with the overall results. Finally, there was no evidence of inconsistency between direct and indirect estimates, with bayesian $\mathrm{P}$ values ranging from 0.06 to 1 (appendix table S7).

\section{Discussion}

This large meta-analysis, with 63242 patients, examined the safety and efficacy profile of second generation durable polymer drug eluting stents (DES) and biodegradable polymer biolimus-ES compared with first generation DES and with each other. Second generation durable polymer everolimus-ES and Resolute zotarolimus-ES, the first generation sirolimus-ES, and the biodegradable polymer biolimus-ES were similar to each other with regards to their efficacy and significantly better than Endeavor zotarolimus-ES and paclitaxel-ES with regards to coronary revascularisations. There was a safety gradient, with everolimus-ES and Resolute zotarolimus-ES resulting in lowest rates of death and myocardial infarction and, conversely, biodegradable polymer biolimus-ES, Endeavor zotarolimus-ES, and paclitaxel-ES being associated with significantly increased odds of myocardial infarction or stent thrombosis compared with everolimus-ES.

Possibly one of our most important findings was the significant increase in the odds of myocardial infarction with biodegradable polymer biolimus-ES compared with durable polymer everolimus-ES. To date, biodegradable polymer biolimus-ES have been perceived as safer than first generation sirolimus-ES and non-inferior to second generation everolimus-ES, mainly on the basis of results from individual trials powered only for composite endpoints of safety and efficacy. ${ }^{79}{ }^{10} \mathrm{We}$ analysed single (instead of composite) endpoints of safety and have provided new insights suggesting that biodegradable polymer biolimus-ES is associated with similar (not higher) safety compared with the first generation sirolimus-ES and with a significantly higher rate of myocardial infarction compared with everolimus-ES. Indeed, the second generation durable polymer everolimus-ES and Resolute zotarolimus-ES were associated with the most favourable safety profile compared with not only the first generation durable polymer paclitaxel-ES but also the second generation Endeavor zotarolimus-ES and biodegradable polymer biolimus-ES. In a wider perspective, this study shows that among all devices compared, the durable polymer second generation everolimus-ES and Resolute zotarolimus-ES are the safest DES to date.

Our findings agree with those of two previous network meta-analyses ${ }^{45}$ that compared first and second generation DES with bare metal stents (BMS). The current meta-analysis,

however, substantially differs from the others by incorporating the most recent evidence from head-to-head DES comparison trials and forming the largest DES database ever analysed, with a total of 63242 patients. We also included biodegradable polymer biolimus-ES, which are used mainly in Europe and Asia, thus providing a comprehensive overview of the most widely used DES in current clinical practice worldwide, not 
compared so far within their class in such a scale for single safety and efficacy endpoints.

Although our exclusion of BMS might be perceived as a limitation, methodological and conceptual reasons dictated such a choice. For a network meta-analysis to provide the highest degree of precision, robust direct and indirect evidence is required. This would not have been possible if we had included BMS as, to date, the direct comparison between biodegradable polymer biolimus-ES and BMS is limited to a single trial, making indirect comparisons through this "weak" common link imprecise and meaningful conclusions difficult. ${ }^{106}$ Moreover, the safety and efficacy of durable polymer "limus"-ES compared with BMS has already been clarified. ${ }^{45}$ Our study differs in design and in the number of included patients from a previous meta-analysis of three randomised controlled trials comparing biodegradable devices with sirolimus-ES, which found a reduction of stent thrombosis associated with biodegradable stents. ${ }^{107}$ The devices pooled in the previous study under the biodegradable group were in fact three distinct types, only one of which is a biodegradable polymer biolimus-ES; all of them represent differences in terms of the biodegradable polymer used, the eluted drug, and stent strut thickness. To provide the most robust conclusions and avoid heterogeneity that might arise by pooling stents with different properties, we decided to include only biodegradable polymer biolimus-ES in this analysis.

\section{Safety}

The safety of first generation DES has been extensively debated. The relatively high rates of stent thrombosis associated with these devices, a phenomenon that translates into increased rates of death or myocardial infarction, raised concerns regarding their widespread use, despite the clear efficacy benefits over BMS. ${ }^{12}$ Further studies showed that the mechanisms of stent thrombosis after DES implantation are complex, with factors related to device design being of paramount importance. Indeed, the inflammation induced by the durable polymers of first generation DES could result in delayed healing and incomplete covering of stent struts by new and functional endothelium, with uncovered stent struts serving as a source for future episodes of stent thrombosis. ${ }^{3}$ Other factors such as stent malapposition and mechanical tissue injury caused by stent struts during implantation, however, also play a role in stent thrombosis. ${ }^{20}$ New generation DES have dealt with the limitations observed with first generation devices in different ways; biodegradable polymer biolimus-ES use abluminal biodegradable polymers that dissolve within six to nine months, with the residual metal platform presumably regaining a safety profile similar to a BMS beyond this time frame. ${ }^{108}$ Conversely, second generation durable polymer DES have replaced first generation polymers with more biocompatible and thinner polymers. ${ }^{109-111}$ Interestingly, the design improvements of the new generation durable polymer DES have run in parallel with a reduction of definite stent thrombosis rates, compared with the first generation paclitaxel-ES and sirolimus-ES in both early and late and very late phases of follow-up. ${ }^{479}$ Furthermore late stent thrombosis, with everolimus-ES being the first and most studied prototype, is reduced not only compared with first generation DES but also with BMS, suggesting that the durable fluoropolymer used in these devices might be "thromboresistant" and more biocompatible than $\mathrm{BMS},{ }^{4-6}$ in turn generating a shift from the contention of an increased risk of stent thrombosis with DES compared with BMS towards the converse relation. In contrast, biodegradable polymer biolimus-ES have failed to provide a significant reduction in one year stent thrombosis rates compared with sirolimus-ES, with both available trials showing a numerical advantage of sirolimus-ES. ${ }^{78}$ Although the five year follow-up of LEADERS ${ }^{44}$ - the only available trial with a long follow-up-shows a significant reduction of the one to five year rates of stent thrombosis compared with sirolimus-ES, the overall rate at five years was not significantly lower than for sirolimus-ES, pointing once more to the impact of first year outcomes. In our analysis, the stent thrombosis outcomes continue to favour the newer generation durable polymer DES, particularly everolimus-ES.

Stent thrombosis, however, remains a surrogate safety endpoint and needs to be interpreted in the context of objective safety endpoints such as death and myocardial infarction. We found that the durable polymer DES yielded lower odds of death and myocardial infarction compared with biodegradable polymer biolimus-ES, with everolimus-ES reaching a significant reduction in myocardial infarction. Of note, this finding is in line with the results of the NEXT and COMPARE II trials, ${ }^{10}$ both of which showed a numerical reduction of myocardial infarction associated with everolimus-ES compared with biodegradable polymer biolimus-ES, which became significant for Q-wave myocardial infarction in the latter. The advantage with regards to myocardial infarction observed with thin strut devices such as everolimus-ES might be related not only to stent thrombosis but also to lower rates of periprocedural myocardial infarction resulting from side branch jailing, which in turn for mechanistic reasons might be more frequent with thick strut devices. ${ }^{112}$ Higher degrees of re-endothelialisation achievable with these stents compared with the thick strut devices have been shown in preclinical ${ }^{113}$ and optical coherence tomography studies $^{114}$ and might also play a role. Our findings on safety among different DES should also be viewed in the context of patients treated with DES who need to undergo non-cardiac surgery; surgery represents one of the most common reasons for premature discontinuation of antiplatelet therapy, which is associated with a significant increase in mortality and major adverse cardiac events. ${ }^{115}$ Indeed, the favourable profile observed with second generation DES might become clinically relevant in this context, in light of recent studies suggesting the safety of shorter overall duration of dual antiplatelet therapy (three to six months) in patients treated with these devices. ${ }^{116} 117$ In this perspective, newer thin strut biodegradable polymer DES recently introduced in the market might have the potential to enhance safety and efficacy outcomes after percutaneous coronary intervention (BIO-RESORT, TWENTE III (NCT01674803) and EVOLVE II QCA (NCT01787799)). Analyses beyond one year confirmed maintenance of the direction of the estimates observed at one year follow-up.

\section{Efficacy}

Factors related to design, such as strut thickness, type of antiproliferative agent, drug elution kinetics, and elution time, as well as type of polymer, could all affect efficacy outcomes. ${ }^{118}{ }^{119} \mathrm{We}$ found that the new generation everolimus-ES, biodegradable polymer biolimus-ES, Resolute zotarolimus-ES, and the first generation sirolimus-ES were associated with reduced rates of target lesion and target vessel revascularisation compared with Endeavor zotarolimus-ES and/or first generation paclitaxel-ES. Our findings therefore confirm on a larger scale the comparable efficacy of biodegradable polymer biolimus-ES and second generation DES shown in the recent NEXT trial, powered for target lesion revascularisation as primary endpoint. ${ }^{10}$

Although not a new finding, in this analysis all "limus"-ES, with the exception of Endeavor zotarolimus-ES, were associated with significantly lower rates of target lesion and target vessel 
revascularisation than the first generation paclitaxel-ES. This finding could derive from the differences in the healing process after implantation between paclitaxel and limus eluting stents. Indeed, the toxicity caused by the long lasting presence of paclitaxel in the vessel wall could give rise to acellular healing process, with prolonged fibrin deposition and inflammation, as shown in preclinical and postmortem studies. ${ }^{3}{ }^{120}$ On the other hand, with Endeavor zotarolimus-ES, short release kinetics could result in insufficient inhibition of neointimal hyperplasia. Indeed, the more recently introduced Resolute zotarolimus-ES, which has a much longer (up to 180 days) release curve of the same antiproliferative agent, zotarolimus, is associated with a significant reduction in target lesion and target vessel revascularisation compared with Endeavor zotarolimus-ES.

\section{Limitations}

As with any meta-analysis, our study shares the limitations of the original studies. Results were analysed on trial level data, and therefore we could not assess whether all baseline characteristics were balanced among groups (although for the most part they were balanced within each randomised controlled trial). Data for follow-up beyond a year were limited but seem to confirm the direction of the estimates at one year. The criteria for inclusion of patients of this meta-analysis were broad, more closely reflecting current practice, comprising both stable and unstable high risk patients. Potentially heterogeneous definitions of myocardial infarction used across the trials could represent another limitation. There was no evidence of significant statistical inconsistency among trials; heterogeneity among trials was found to be moderate for stent thrombosis and low to moderate for target lesion and target vessel revascularisation. On the other hand, the stability of the results in the sensitivity analyses confirms that the overall outcome effect is robust and justified. Another aspect is the duration of dual antiplatelet therapy (the combination of aspirin and a P2Y12 receptor blocker), which varied among the different trials. The variability of dual antiplatelet therapy, however, could be less important in the context of the present meta-analysis given that BMS were excluded and most trials used at least six months of dual antiplatelet therapy (a summary of current guideline recommendations ${ }^{121}$ is in the appendix). Because of the limited number of trials that assessed Resolute zotarolimus-ES, the findings with this device should be viewed as exploratory but certainly deserve further attention.

Despite these limitations, this network meta-analysis provides the largest scale comparative information on the efficacy and safety profiles of different DES in current use.

\section{Conclusions}

Biodegradable polymer biolimus-ES show a similar efficacy and safety profile to first generation sirolimus-ES. Compared with second generation everolimus-ES and Resolute zotarolimus-ES, biodegradable polymer biolimus-ES again provide similar efficacy outcomes. Safety outcomes, however, favour both everolimus-ES and Resolute zotarolimus-ES, suggesting that these second generation durable polymer stents are the safest for current clinical practice.

Contributors: EK and EPN designed the analysis. EPN, KT, BC, and $M K$ and EK collected and abstracted the data. EPN carried out the statistical analysis; EPN and EK drafted the manuscript. All authors analysed and interpreted the data and critically revised the manuscript for important intellectual content. The contents of this study are solely the responsibility of the authors and do not necessarily represent the official view of their institutions or any other party. EPN and EK are guarantors.

Funding: This research received no specific grant from any funding agency in the public, commercial, or not-for-profit sectors.

Competing interests: All authors have completed the ICMJE uniform disclosure form at www.icmje.org/coi_disclosure.pdf (available on request from the corresponding author) and declare that DEK has received research/grant support from Boston Scientific, Medtronic, and Abbott Vascular and has served as consultant for Boston Scientific, Medtronic, and Micell Technologies; DJK has received grant/research support from, been a consultant to, and served on the advisory board for Abbott Vascular and Boston Scientific; CvB is a consultant to and/or has received lecture fees or travel expenses from Abbott Vascular, Boston Scientific, and Medtronic; The Cardiology Research Department of Thoraxcentrum Twente has received educational and/or research grants from Abbott Vascular, Biotronik, Boston Scientific, and Medtronic; AVF has sponsored research agreements with Boston Scientific and Medtronic Vascular and serves on the advisory board for Medtronic Vascular; EK is a consultant to and/or has received lecture fees or travel expenses from Abbott Vascular, and Medtronic; The Maasstad Cardiology Department (previous working place) has received educational and/or research grants funded by Abbott Vascular, Boston Scientific, Terumo Europe, and Medtronic; ITM serves as a consultant to Boston Scientific and Medtronic. All the other authors report no conflict of interest related to the present article.

Ethical approval: Not required.

Data sharing: No additional data available

Declaration of transparency: The lead author (the manuscript's guarantor) affirms that the manuscript is an honest, accurate, and transparent account of the study being reported; that no important aspects of the study have been omitted; and that any discrepancies from the study as planned (and, if relevant, registered) have been explained.

1 Camenzind E, Steg PG, Wijns W. Stent thrombosis late after implantation of first-generation drug-eluting stents: a cause for concern. Circulation 2007;115:1440-55.

2 Daemen J, Wenaweser P, Tsuchida K, Abrecht L, Vaina S, Morger C, et al. Early and late coronary stent thrombosis of sirolimus-eluting and paclitaxel-eluting stents in routine clinical practice: data from a large two-institutional cohort study. Lancet 2007:369:667-78.

3 Joner M, Finn AV, Farb A, Mont EK, Kolodgie FD, Ladich E, et al. Pathology of drug-eluting stents in humans: delayed healing and late thrombotic risk. J Am Coll Cardiol 2006;48:193-202.

4 Palmerini T, Biondi-Zoccai G, Della Riva D, Stettler C, Sangiorgi D, D'Ascenzo F, et al. Stent thrombosis with drug-eluting and bare-metal stents: evidence from a comprehensive network meta-analysis. Lancet 2012;379:1393-402.

5 Bangalore S, Kumar S, Fusaro M, Amoroso N, Attubato MJ, Feit F, et al. Short- and long-term outcomes with drug-eluting and bare-metal coronary stents: a mixed-treatment comparison analysis of 117762 patient-years of follow-up from randomized trials. Circulation 2012;125:2873-91

6 Sabate M, Cequier A, Iniguez A, Serra A, Hernandez-Antolin R, Mainar V, et al. Everolimus-eluting stent versus bare-metal stent in ST-segment elevation myocardial infarction (EXAMINATION): 1 year results of a randomised controlled trial. Lancet 2012;380:1482-90.

7 Windecker S, Serruys PW, Wandel S, Buszman P, Trznadel S, Linke A, et al. Biolimus-eluting stent with biodegradable polymer versus sirolimus-eluting stent with durable polymer for coronary revascularisation (LEADERS): a randomised non-inferiority trial. Lancet 2008;372:1163-73.

8 Christiansen EH, Jensen LO, Thayssen P, Tilsted HH, Krusell LR, Hansen KN, et al. Biolimus-eluting biodegradable polymer-coated stent versus durable polymer-coated sirolimus-eluting stent in unselected patients receiving percutaneous coronary intervention (SORT OUT V): a randomised non-inferiority trial. Lancet 2013;381:661-9.

9 Smits PC, Hofma S, Togni M, Vazquez N, Valdes M, Voudris V, et al. Abluminal biodegradable polymer biolimus-eluting stent versus durable polymer everolimus-eluting stent (COMPARE II): a randomised, controlled, non-inferiority trial. Lancet 2013:381:651-60.

10 Natsuaki M, Kozuma K, Morimoto T, Kadota K, Muramatsu T, Nakagawa Y, et al. Biodegradable polymer biolimus-eluting stent versus durable polymer everolimus-eluting stent: a randomized, controlled, noninferiority trial. J Am Coll Cardiol 2013:62:181-90.

11 Cutlip DE, Windecker S, Mehran R, Boam A, Cohen DJ, van Es GA, et al. Clinical end points in coronary stent trials: a case for standardized definitions. Circulation 2007;115:2344-51.

12 Higgins JPT, Green D. Cochrane handbook for systematic reviews of interventions. Version 5.1.0. Cochrane Collaboration, 2011. www.cochrane-handbook.org

13 Cooper NJ, Peters J, Lai MC, Juni P, Wandel S, Palmer S, et al. How valuable are multiple treatment comparison methods in evidence-based health-care evaluation? Value Health 2011:14:371-80.

14 Dias S, Welton NJ, Caldwell DM, Ades AE. Checking consistency in mixed treatment comparison meta-analysis. Stat Med 2010;29:932-44. 


\section{What is already known on this topic}

Coronary stents are widely used to treat patients with coronary artery disease, with drug eluting stents (DES) being more efficacious than bare metal stents

Among DES, the second generation durable polymer stents (with everolimus eluting being the most studied prototype) are safer than first generation durable polymer DES and bare metal stents

The efficacy and safety profile of biodegradable polymer stents (with biolimus eluting being the most widely used) compared with first and second generation durable polymer DES is controversial

\section{What this study adds}

This large network meta-analysis of randomised trials on DES compares durable with biodegradable polymer stents and provides a clear visual ranking of the efficacy and safety of all of the most used DES

The newer durable polymer everolimus and Resolute zotarolimus eluting stents, as well as the biodegradable polymer biolimus eluting stents, provide similar efficacy to first generation sirolimus eluting stents. Everolimus and Resolute zotarolimus eluting stents are the safest devices to date

15 Spiegelhalter D, Abrams K, Myles J. Bayesian approaches to clinical trials and health-care evaluation (Statistics in Practice). Wiley, 2004.

16 Kaiser C, Brunner-La Rocca HP, Buser PT, Bonetti PO, Osswald S, Linka A, et al. Incremental cost-effectiveness of drug-eluting stents compared with a third-generation bare-metal stent in a real-world setting: randomised Basel Stent Kosten Effektivitats Trial (BASKET). Lancet 2005;366:921-9.

17 Kaiser C, Galatius S, Erne P, Eberli F, Alber H, Rickli H, et al. Drug-eluting versus bare-metal stents in large coronary arteries. N Engl J Med 2010;363:2310-9.

18 Park HJ, Kim HY, Lee JM, Choi YS, Park CS, Kim DB, et al. Randomized comparison of the efficacy and safety of zotarolimus-eluting stents vs. sirolimus-eluting stents for percutaneous coronary intervention in chronic total occlusion-CAtholic Total Occlusion Study (CATOS) trial. Circ J 2012;76:868-75.

19 Moreno R, Garcia E, Teles R, Rumoroso JR, Carvalho HC, Goicolea FJ, et al. Randomized comparison of sirolimus-eluting and everolimus-eluting coronary stents in the treatment of total coronary occlusions: results from the chronic coronary occlusion treated by everolimus-eluting stent randomized trial. Circ Cardiovasc Interv 2013;6:21-8.

20 Kedhi E, Joesoef KS, McFadden E, Wassing J, van Mieghem C, Goedhart D, et al. Second-generation everolimus-eluting and paclitaxel-eluting stents in real-life practice (COMPARE): a randomised trial. Lancet 2010;375:201-9.

21 Smits PC, Kedhi E, Royaards KJ, Joesoef KS, Wassing J, Rademaker-Havinga TA, et al. 2-year follow-up of a randomized controlled trial of everolimus- and paclitaxel-eluting stents for coronary revascularization in daily practice. COMPARE (Comparison of the everolimus eluting XIENCE-V stent with the paclitaxel eluting TAXUS LIBERTE stent in all-comers: a randomized open label trial). J Am Coll Cardiol 2011;58:11-8.

22 De Lezo J, Medina A, Pan M, Romero M, Delgado A, Segura J, et al. Drug-eluting stents for complex lesions: randomized rapamycin versus paclitaxel CORPAL study. J Am Coll Cardiol 2005:45:75A.

23 Wang L, Zhang D, Yang X, Ge Y, Wang H, Li W, et al. Comparison of safety and efficacy of Cypher $\AA$ stent and Endeavor ${ }^{\circledR}$ stent in patients with acute ST elevation myocardial infarction (STEMI) undergoing emergency PCI. J Am Coll Cardiol 2011;58:B216.

24 Lee SW, Park SW, Kim YH, Yun SC, Park DW, Lee CW, et al. A randomized comparison of sirolimus- versus paclitaxel-eluting stent implantation in patients with diabetes mellitus 2-year clinical outcomes of the DES-DIABETES trial. J Am Coll Cardiol 2009;53:812-3.

25 Lee SW, Park SW, Kim YH, Yun SC, Park DW, Lee CW, et al. A randomized comparison of sirolimus- versus paclitaxel-eluting stent implantation in patients with diabetes mellitus: 4-year clinical outcomes of DES-DIABETES (drug-eluting stent in patients with DIABETES mellitus) trial. JACC Cardiovasc Interv 2011;4:310-6.

26 Maeng M, Jensen LO, Galloe AM, Thayssen P, Christiansen EH, Hansen KN, et al. Comparison of the sirolimus-eluting versus paclitaxel-eluting coronary stent in patients with diabetes mellitus: the diabetes and drug-eluting stent (DiabeDES) randomized angiography trial. Am J Cardiol 2009;103:345-9.

27 Kandzari DE, Leon MB, Popma JJ, Fitzgerald PJ, O'Shaughnessy C, Ball MW, et al. Comparison of zotarolimus-eluting and sirolimus-eluting stents in patients with native coronary artery disease: a randomized controlled trial. J Am Coll Cardiol 2006;48:2440-7.

28 Kandzari DE, Mauri L, Popma JJ, Turco MA, Gurbel PA, Fitzgerald PJ, et al Late-term clinical outcomes with zotarolimus- and sirolimus-eluting stents. 5-year follow-up of the ENDEAVOR III (a randomized controlled trial of the medtronic endeavor drug [abt-578] eluting coronary stent system versus the cypher sirolimus-eluting coronary stent system in de novo native coronary artery lesions). JACC Cardiovasc Interv 2011;4:543-50.

29 Leon MB, Mauri L, Popma JJ, Cutlip DE, Nikolsky E, O'Shaughnessy C, et al. A randomized comparison of the ENDEAVOR zotarolimus-eluting stent versus the TAXUS paclitaxel-eluting stent in de novo native coronary lesions 12-month outcomes from the ENDEAVOR IV trial. J Am Coll Cardiol 2010;55:543-54

30 Kirtane AJ, Leon MB, Ball MW, Bajwa HS, Sketch MH,Jr, Coleman PS, et al. The "final" 5 -year follow-up from the ENDEAVOR IV trial comparing a Zotarolimus-eluting stent with a Paclitaxel-eluting stent. JACC Cardiovasc Interv 2013;6:325-33.

31 Kim WJ, Lee SW, Park SW, Kim YH, Yun SC, Lee JY, et al. Randomized comparison of everolimus-eluting stent versus sirolimus-eluting stent implantation for de novo coronary artery disease in patients with diabetes mellitus (ESSENCE-DIABETES): results from the ESSENCE-DIABETES trial. Circulation 2011;124:886-92.

32 Park KW, Chae IH, Lim DS, Han KR, Yang HM, Lee HY, et al. Everolimus-eluting versus sirolimus-eluting stents in patients undergoing percutaneous coronary intervention: the EXCELLENT (Efficacy of Xience/Promus Versus Cypher to Reduce Late Loss After Stenting) randomized trial. J Am Coll Cardiol 2011:58:1844-54.

33 Hong SJ, Kim MH, Cha KS, Park HS, Chae SC, Hur SH, et al. Comparison of three-year clinical outcomes between sirolimus-versus paclitaxel-eluting stents in diabetic patients: prospective randomized multicenter trial. Catheter Cardiovasc Interv 2010;76:924-33.

34 Dibra A, Kastrati A, Mehilli J, Pache J, Schuhlen H, von Beckerath N, et al. Paclitaxel-eluting or sirolimus-eluting stents to prevent restenosis in diabetic patients. $\mathrm{N}$ Engl J Med 2005;353:663-70.

35 Mehilli J, Kastrati A, Byrne RA, Bruskina O, lijima R, Schulz S, et al. Paclitaxel- versus sirolimus-eluting stents for unprotected left main coronary artery disease. J Am Coll Cardiol 2009;53:1760-8
36 Mehilli J, Richardt G, Valgimigli M, Schulz S, Singh A, Abdel-Wahab M, et al. Zotarolimusversus Everolimus-eluting stents for unprotected left main coronary artery disease. J Am Coll Cardiol 2013;Aug 8. doi:S0735-1097(13)03074-X

37 Mehilli J, Dibra A, Kastrati A, Pache J, Dirschinger J, Schomig A, et al. Randomized trial of paclitaxel- and sirolimus-eluting stents in small coronary vessels. Eur Heart $J$ 2006;27:260-6.

38 Byrne RA, Mehilli J, lijima R, Schulz S, Pache J, Seyfarth M, et al. A polymer-free dual drug-eluting stent in patients with coronary artery disease: a randomized trial vs. polymer-based drug-eluting stents. Eur Heart J 2009;30:923-31.

39 Byrne RA, Kastrati A, Tiroch K, Schulz S, Pache J, Pinieck S, et al. 2-year clinical and angiographic outcomes from a randomized trial of polymer-free dual drug-eluting stents versus polymer-based Cypher and Endeavor [corrected] drug-eluting stents. J Am Coll Cardiol 2010;55:2536-43.

40 Juwana YB, Suryapranata H, Ottervanger JP, De Luca G, van't Hof AW, Dambrink JH, et al. Comparison of rapamycin- and paclitaxel-eluting stents in patients undergoing primary percutaneous coronary intervention for ST-elevation myocardial infarction. Am J Cardiol 2009;104:205-9.

41 Kamoi D, Ishii H, Takahashi H, Aoyama T, Toriyama T, Tanaka M, et al. Sirolimus- vs. paclitaxel-eluting stent to coronary intervention in dialysis patients. Int $J$ Cardiol 2013;165:533-6.

42 Kim MH, Hong SJ, Cha KS, Park HS, Chae SC, Hur SH, et al. Effect of Paclitaxel-eluting versus sirolimus-eluting stents on coronary restenosis in Korean diabetic patients. J Interv Cardiol 2008;21:225-31.

43 Kang WC, Ahn T, Lee K, Han SH, Shin EK, Jeong MH, et al. Comparison of zotarolimus-eluting stents versus sirolimus-eluting stents versus paclitaxel-eluting stents for primary percutaneous coronary intervention in patients with ST-elevation myocardial infarction: results from the Korean Multicentre Endeavor (KOMER) acute myocardial infarction (AMI) trial. Eurolntervention 2011;7:936-43.

44 Serruys PW, Farooq V, Kalesan B, de Vries T, Buszman P, Linke A, et al. Improved safety and reduction in stent thrombosis associated with biodegradable polymer-based biolimus-eluting stents versus durable polymer-based sirolimus-eluting stents in patients with coronary artery disease: final 5-year report of the LEADERS (Limus Eluted From A Durable Versus ERodable Stent Coating) randomized, noninferiority trial. JACC CardiovasC Interv 2013;6:777-89.

45 Kim YH, Park SW, Lee SW, Park DW, Yun SC, Lee CW, et al. Sirolimus-eluting stent versus paclitaxel-eluting stent for patients with long coronary artery disease. Circulation 2006;114:2148-53.

46 Park DW, Kim YH, Song HG, Ahn JM, Kim WJ, Lee JY, et al. Comparison of everolimusand sirolimus-eluting stents in patients with long coronary artery lesions: a randomized LONG-DES-III (Percutaneous Treatment of LONG Native Coronary Lesions With Drug-Eluting Stent-III) Trial. JACC Cardiovasc Interv 2011;4:1096-103.

47 Ahn JM, Park DW, Kim YH, Song H, Cho YR, Kim WJ, et al. Comparison of resolute zotarolimus-eluting stents and sirolimus-eluting stents in patients with de novo long coronary artery lesions: a randomized LONG-DES IV trial. Circ Cardiovasc Interv 2012;5:633-40.

48 Briguori C, Airoldi F, Visconti G, Focaccio A, Caiazzo G, Golia B, et al. Novel approaches for preventing or limiting events in diabetic patients (Naples-diabetes) trial: a randomized comparison of 3 drug-eluting stents in diabetic patients. Circ Cardiovasc Interv 2011;4:121-9

49 Chevalier B, Serruys PW, Silber S, Garcia E, Suryapranata H, Hauptmann K, et al. Randomised comparison of Nobori, biolimus A9-eluting coronary stent with a Taxus $(R)$, paclitaxel-eluting coronary stent in patients with stenosis in native coronary arteries: the Nobori 1 trial. Eurolntervention 2007:2:426-34.

50 Chevalier B, Silber S, Park SJ, Garcia E, Schuler G, Suryapranata H, et al. Randomized comparison of the Nobori Biolimus A9-eluting coronary stent with the Taxus Liberte paclitaxel-eluting coronary stent in patients with stenosis in native coronary arteries: the NOBORI 1 trial-phase 2. Circ Cardiovasc Interv 2009;2:188-95.

51 Kadota K, Muramatsu T, Iwabuchi M, Saito S, Hayashi Y, Ikari Y, et al. Randomized comparison of the Nobori biolimus A9-eluting stent with the sirolimus-eluting stent in patients with stenosis in native coronary arteries. Catheter Cardiovasc Interv 2012;80:789-96

52 Kimura T, Muramatsu T, Iwabuchi M, Saito S, Hayashi Y, Ikari Y. Three year follow up of a randomized comparison of Nobori, biolimus A9 eluting stent(BES) with Cypher, sirolimus eluting stent(SES) for coronary revascularization in japanese population. J Am Coll Cardiol 2012;17S:B216.

53 Pan M, Suarez de Lezo J, Medina A, Romero M, Delgado A, Segura J, et al. Drug-eluting stents for the treatment of bifurcation lesions: a randomized comparison between paclitaxe and sirolimus stents. Am Heart J 2007;153:15.e1-7.

54 Di Lorenzo E, Sauro R, Varricchio A, Capasso M, Lanzillo T, Manganelli F, et al. Benefits of drug-eluting stents as compared to bare metal stent in ST-segment elevation myocardia infarction: four year results of the PaclitAxel or Sirolimus-eluting stent vs bare metal stent in primary angiOplasty (PASEO) randomized trial. Am Heart J 2009;158:e43-50. 
55 Petronio AS, De Carlo M, Branchitta G, Papini B, Ciabatti N, Gistri R, et al. Randomized comparison of sirolimus and paclitaxel drug-eluting stents for long lesions in the left anterio descending artery: an intravascular ultrasound study. J Am Coll Cardiol 2007;49:539-46.

56 Van den Branden BJ, Teeuwen K, Koolen JJ, van der Schaaf RJ, Henriques JP, Tijssen JG, et al. Primary Stenting of Totally Occluded Native Coronary Arteries III (PRISON III): a randomised comparison of sirolimus-eluting stent implantation with zotarolimus-eluting stent implantation for the treatment of total coronary occlusions. Eurolntervention 2013;Apr 30. doi:20120819-01

57 Lee JH, Kim HS, Lee SW, Park JH, Choi SW, Jeong JO, et al. Prospective randomized comparison of sirolimus- versus paclitaxel-eluting stents for the treatment of acute ST-elevation myocardial infarction: pROSIT trial. Catheter Cardiovasc Interv 2008;72:25-32.

58 Kim HS, Lee JH, Lee SW, Kim YH, Park JH, Choi SW, et al. Long-term safety and efficacy of sirolimus- vs. paclitaxel-eluting stent implantation for acute ST-elevation myocardial infarction: 3-year follow-up of the PROSIT trial. Int J Cardiol 2011;147:253-7.

59 Camenzind E, Wijns W, Mauri L, Kurowski V, Parikh K, Gao R, et al. Stent thrombosis and major clinical events at 3 years after zotarolimus-eluting or sirolimus-eluting coronary stent implantation: a randomised, multicentre, open-label, controlled trial. Lancet 2012;380:1396-405

60 Xu B, Yang Y, Yuan Z, Du Z, Wong SC, Genereux P, et al. Zotarolimus- and paclitaxel-eluting stents in an all-comer population in China: the RESOLUTE China randomized controlled trial. JACC Cardiovasc Interv 2013;6:664-70.

61 Morice MC, Colombo A, Meier B, Serruys P, Tamburino C, Guagliumi G, et al. Sirolimusvs paclitaxel-eluting stents in de novo coronary artery lesions: the REALITY trial: a randomized controlled trial. JAMA 2006;295:895-904

62 Kimura T, Morimoto T, Natsuaki M, Shiomi H, Igarashi K, Kadota K, et al. Comparison of everolimus-eluting and sirolimus-eluting coronary stents: 1-year outcomes from the Randomized Evaluation of Sirolimus-eluting Versus Everolimus-eluting stent Trial (RESET). Circulation 2012;126:1225-36.

63 Serruys PW, Silber S, Garg S, van Geuns RJ, Richardt G, Buszman PE, et al. Comparison of zotarolimus-eluting and everolimus-eluting coronary stents. $N$ Engl $\mathrm{J} \mathrm{Med}$ 2010;363:136-46

64 Silber S, Windecker S, Vranckx P, Serruys PW, RESOLUTE All Comers investigators. Unrestricted randomised use of two new generation drug-eluting coronary stents: 2-year patient-related versus stent-related outcomes from the RESOLUTE All Comers trial. Lancet 2011;377:1241-7.

65 Burzotta F, Trani C, Todaro D, Mariani L, Talarico GP, Tommasino A, et al. Prospective randomized comparison of sirolimus- or everolimus-eluting stent to treat bifurcated lesions by provisional approach. JACC Cardiovasc Interv 2011:4:327-35.

66 Separham A, Sohrabi B, Aslanabadi N, Ghaffari S. The twelve-month outcome of biolimus eluting stent with biodegradable polymer compared with an everolimus eluting stent with durable polymer. J Cardiovasc Thorac Res 2011;3:113-6.

67 Windecker S, Remondino A, Eberli FR, Juni P, Raber L, Wenaweser P, et al. Sirolimus-eluting and paclitaxel-eluting stents for coronary revascularization. $N$ Engl $J$ Med 2005;353:653-62.

68 Raber L, Wohlwend L, Wigger M, Togni M, Wandel S, Wenaweser $\mathrm{P}$, et al. Five-year clinical and angiographic outcomes of a randomized comparison of sirolimus-eluting and paclitaxel-eluting stents: results of the Sirolimus-Eluting Versus Paclitaxel-Eluting Stents for Coronary Revascularization LATE trial. Circulation 2011;123:2819-28.

69 Galloe AM, Thuesen L, Kelbaek H, Thayssen P, Rasmussen K, Hansen PR, et al. Comparison of paclitaxel- and sirolimus-eluting stents in everyday clinical practice: the SORT OUT II randomized trial. JAMA 2008:299:409-16.

70 Rasmussen K, Maeng M, Kaltoft A, Thayssen P, Kelbaek H, Tilsted HH, et al. Efficacy and safety of zotarolimus-eluting and sirolimus-eluting coronary stents in routine clinical care (SORT OUT III): a randomised controlled superiority trial. Lancet 2010;375:1090-9.

71 Maeng M, Tilsted HH, Jensen LO, Kaltoft A, Kelbaek H, Abildgaard U, et al. 3-Year clinical outcomes in the randomized SORT OUT III superiority trial comparing zotarolimus- and sirolimus-eluting coronary stents. JACC Cardiovasc Interv 2012;5:812-8.

72 Jensen LO, Thayssen P, Hansen HS, Christiansen EH, Tilsted HH, Krusell LR, et al. Randomized comparison of everolimus-eluting and sirolimus-eluting stents in patients treated with percutaneous coronary intervention: the Scandinavian Organization for Randomized Trials with Clinical Outcome IV (SORT OUT IV). Circulation 2012;125:1246-55

73 Jensen LO, Thayssen P, Christiansen EH, Tilsted HH, Maeng M, Hansen KN, et al. 2-yea patient-related versus stent-related outcomes: the SORT OUT IV (Scandinavian Organization for Randomized Trials With Clinical Outcome IV) Trial. J Am Coll Cardiol 2012;60:1140-7

74 Serruys PW, Ruygrok P, Neuzner J, Piek JJ, Seth A, Schofer JJ, et al. A randomised comparison of an everolimus-eluting coronary stent with a paclitaxel-eluting coronary stent: the SPIRIT II trial. Eurolntervention 2006;2:286-94.

75 Onuma Y, Miquel-Hebert K, Serruys PW, SPIRIT II Investigators. Five-year long-term clinical follow-up of the XIENCE V everolimus-eluting coronary stent system in the treatment of patients with de novo coronary artery disease: the SPIRIT II trial. Eurolntervention 2013;8:1047-51.

76 Stone GW, Midei M, Newman W, Sanz M, Hermiller JB, Williams J, et al. Comparison of an everolimus-eluting stent and a paclitaxel-eluting stent in patients with coronary artery disease: a randomized trial. JAMA 2008;299:1903-13.

77 Applegate RJ, Yaqub M, Hermiller JB, Sood P, Yu S, Doostzadeh J, et al. Long-term (three-year) safety and efficacy of everolimus-eluting stents compared to paclitaxel-eluting stents (from the SPIRIT III Trial). Am J Cardiol 2011;107:833-40.

78 Stone GW, Rizvi A, Newman W, Mastali K, Wang JC, Caputo R, et al. Everolimus-eluting versus paclitaxel-eluting stents in coronary artery disease. N Engl J Med 2010:362:1663-74.

79 Stone GW, Rizvi A, Sudhir K, Newman W, Applegate RJ, Cannon LA, et al. Randomized comparison of everolimus- and paclitaxel-eluting stents. 2-year follow-up from the SPIRIT (Clinical Evaluation of the XIENCE V Everolimus Eluting Coronary Stent System) IV trial. J Am Coll Cardiol 2011;58:19-25

80 Grube E, Chevalier B, Guagliumi G, Smits PC, Stuteville M, Dorange C, et al. The SPIRIT $\checkmark$ diabetic study: a randomized clinical evaluation of the XIENCE $V$ everolimus-eluting stent vs the TAXUS Liberte paclitaxel-eluting stent in diabetic patients with de novo coronary artery lesions. Am Heart J 2012;163:867,875.e1.

81 Goy JJ, Stauffer JC, Siegenthaler M, Benoit A, Seydoux C. A prospective randomized comparison between paclitaxel and sirolimus stents in the real world of interventional cardiology: the TAXi trial. J Am Coll Cardiol 2005;45:308-11.

82 Berger A, Stauffer JC, Seydoux C, Siegenthaler M, Benoit A, Goy JJ. Three-year follow-up of the first prospective randomized comparison between paclitaxel and sirolimus stents: the TAXi-LATE trial. Catheter Cardiovasc Interv 2007;70:163-6.
83 von Birgelen C, Basalus MW, Tandjung K, van Houwelingen KG, Stoel MG, Louwerenburg $\mathrm{JH}$, et al. A randomized controlled trial in second-generation zotarolimus-eluting Resolute stents versus everolimus-eluting Xience $V$ stents in real-world patients: the TWENTE trial. J Am Coll Cardiol 2012;59:1350-61.

84 Tandjung K, Sen H, Lam MK, Basalus MW, Louwerenburg JH, Stoel MG, et al. Clinical outcome following stringent discontinuation of dual antiplatelet therapy after 12 months in real-world patients treated with second-generation zotarolimus-eluting resolute and everolimus-eluting Xience V stents: 2-year follow-up of the randomized TWENTE trial. $J$ Am Coll Cardiol 2013; Jun;61:2406-16.

85 Hofma SH, Brouwer J, Velders MA, van't Hof AW, Smits PC, Quere M, et al. Second-generation everolimus-eluting stents versus first-generation sirolimus-eluting stents in acute myocardial infarction. 1-year results of the randomized XAMI (XienceV Stent vs. Cypher Stent in Primary PCl for Acute Myocardial Infarction) trial. J Am Coll Cardiol 2012:60:381-7.

86 Park DW, Kim YH, Yun SC, Kang SJ, Lee SW, Lee CW, et al. Comparison of zotarolimus-eluting stents with sirolimus- and paclitaxel-eluting stents for coronary revascularization: the ZEST (comparison of the efficacy and safety of zotarolimus-eluting stent with sirolimus-eluting and paclitaxel-eluting stent for coronary lesions) randomized trial. J Am Coll Cardiol 2010;56:1187-95.

87 Lee CW, Park DW, Lee SH, Kim YH, Hong MK, Kim JJ, et al. Comparison of the efficacy and safety of zotarolimus-, sirolimus-, and paclitaxel-eluting stents in patients with ST-elevation myocardial infarction. Am J Cardiol 2009;104:1370-6.

88 Zhang Q, Zhang RY, Zhang JS, Hu J, Yang ZK, Ni J, et al. One-year clinical outcomes of Chinese sirolimus-eluting stent in the treatment of unselected patients with coronary artery disease. Chin Med J (Engl) 2006;119:165-8.

89 Kereiakes DJ, Cannon LA, Feldman RL, Popma JJ, Magorien R, Whitbourn R, et al. Clinical and angiographic outcomes after treatment of de novo coronary stenoses with a novel platinum chromium thin-strut stent: primary results of the PERSEUS (Prospective Evaluation in a Randomized Trial of the Safety and Efficacy of the Use of the TAXUS Element Paclitaxel-Eluting Coronary Stent System) trial. J Am Coll Cardiol 2010;56:264-71

90 Kim HS, Park SJ, Park DW, Park SW, Cheong SS, Lee SG, et al. Comparison of the efficacy and safety of paclitaxel-eluting coroflex please stents and paclitaxel-eluting stents in patients with coronary artery disease: a randomized PIPA trial. Catheter Cardiovasc Interv 2012;1;80:799-806.

91 Stone GW, Teirstein PS, Meredith IT, Farah B, Dubois CL, Feldman RL, et al. A prospective, randomized evaluation of a novel everolimus-eluting coronary stent: the PLATINUM (a Prospective, Randomized, Multicenter Trial to Assess an Everolimus-Eluting Coronary Stent System [PROMUS Element] for the Treatment of Up to Two de Novo Coronary Artery Lesions) trial. J Am Coll Cardiol 2011;57:1700-8.

92 Massberg S, Byrne RA, Kastrati A, Schulz S, Pache J, Hausleiter J, et al. Polymer-free sirolimus- and probucol-eluting versus new generation zotarolimus-eluting stents in coronary artery disease: the Intracoronary Stenting and Angiographic Results: Test Efficacy of Sirolimus- and Probucol-Eluting versus Zotarolimus-eluting Stents (ISAR-TEST 5) trial. Circulation 2011:124:624-32.

93 Ormiston JA, Abizaid A, Spertus J, Fajadet J, Mauri L, Schofer J, et al Six-month results of the NEVO Res-Elution I (NEVO RES-I) trial: a randomized, multicenter comparison of the NEVO sirolimus-eluting coronary stent with the TAXUS Liberte paclitaxel-eluting stent in de novo native coronary artery lesions. Circ Cardiovasc Interv 2010;3:556-64.

94 Chevalier B, Di Mario C, Neumann FJ, Ribichini F, Urban P, Popma JJ, et al. A randomized, controlled, multicenter trial to evaluate the safety and efficacy of zotarolimus- versus paclitaxel-eluting stents in de novo occlusive lesions in coronary arteries The ZoMaxx I trial. JACC Cardiovasc Interv 2008;1:524-32.

95 Desch S, Schloma D, Mobius-Winkler S, Erbs S, Gielen S, Linke A, et al. Randomized comparison of a polymer-free sirolimus-eluting stent versus a polymer-based paclitaxel-eluting stent in patients with diabetes mellitus: the LIPSIA Yukon trial. JACC Cardiovasc Interv 2011;4:452-9.

96 Haude M, Erbel R, Erne P, Verheye S, Degen H, Bose D, et al. Safety and performance of the drug-eluting absorbable metal scaffold (DREAMS) in patients with de-novo coronary lesions: 12 month results of the prospective, multicentre, first-in-man BIOSOLVE-I trial. Lancet 2013;381:836-44

97 Waksman R, Barbash IM, Dvir D, Torguson R, Ben-Dor I, Maluenda G, et al. Safety and efficacy of the XIENCE $V$ everolimus-eluting stent compared to first-generation drug-eluting stents in contemporary clinical practice. Am J Cardiol 2012:109:1288-94.

98 Ng VG, Lansky AJ, Hermiller JB, Farhat N, Applegate RJ, Yaqub M, et al. Three-year results of safety and efficacy of the everolimus-eluting coronary stent in women (from the SPIRIT III randomized clinical trial). Am J Cardiol 2011;107:841-8.

99 Kereiakes DJ, Cutlip DE, Applegate RJ, Wang J, Yaqub M, Sood P, et al. Outcomes in diabetic and nondiabetic patients treated with everolimus- or paclitaxel-eluting stents: results from the SPIRIT IV clinical trial (Clinical Evaluation of the XIENCE V Everolimus Eluting Coronary Stent System). J Am Coll Cardiol 2010;56:2084-9.

100 Otake H, Ako J, Yamasaki M, Tsujino I, Shimohama T, Hasegawa T, et al. Comparison of everolimus- versus paclitaxel-eluting stents implanted in patients with diabetes mellitus as evaluated by three-dimensional intravascular ultrasound analysis. Am J Cardiol 2010;106:492-7.

101 Tada T, Byrne RA, Cassese S, King L, Schulz S, Mehilli J, et al. Comparative efficacy of 2 zotarolimus-eluting stent generations: resolute versus endeavor stents in patients with coronary artery disease. Am Heart J 2013;165:80-6.

102 Song YB, Hahn JY, Choi SH, Choi JH, Lee SH, Jeong MH, et al. Sirolimus- versus paclitaxel-eluting stents for the treatment of coronary bifurcations results: from the COBIS (Coronary Bifurcation Stenting) Registry. J Am Coll Cardiol 2010;55:1743-50.

103 Jensen LO, Maeng M, Thayssen P, Villadsen A, Krusell L, Botker HE, et al. Late lumen loss and intima hyperplasia after sirolimus-eluting and zotarolimus-eluting stent implantation in diabetic patients: the diabetes and drug-eluting stent (DiabeDES III) angiography and intravascular ultrasound trial. Eurolntervention 2011;7:323-31.

104 Mehilli J, Byrne RA, Wieczorek A, lijima R, Schulz S, Bruskina O, et al. Randomized trial of three rapamycin-eluting stents with different coating strategies for the reduction of coronary restenosis. Eur Heart J 2008;29:1975-82.

105 Tomai F, Reimers B, De Luca L, Galassi AR, Gaspardone A, Ghini AS, et al. Head-to-head comparison of sirolimus- and paclitaxel-eluting stent in the same diabetic patient with multiple coronary artery lesions: a prospective, randomized, multicenter study. Diabetes Care 2008;31:15-9.

106 Caldwell DM, Ades AE, Higgins JP. Simultaneous comparison of multiple treatments: combining direct and indirect evidence. BMJ 2005;331:897-900

107 Stefanini GG, Byrne RA, Serruys PW, de Waha A, Meier B, Massberg S, et al. Biodegradable polymer drug-eluting stents reduce the risk of stent thrombosis at 4 years 
in patients undergoing percutaneous coronary intervention: a pooled analysis of individual patient data from the ISAR-TEST 3, ISAR-TEST 4, and LEADERS randomized trials. Eur Heart J 2012;33:1214-22.

108 Navarese EP, Castriota F, Sangiorgi GM, Cremonesi A. From the abluminal biodegradable polymer stent to the polymer free stent. Clinical evidence. Minerva Cardioangiol 2013;61:243-54.

109 Kolandaivelu K, Swaminathan R, Gibson WJ, Kolachalama VB, Nguyen-Ehrenreich KL, Giddings $\mathrm{VL}$, et al. Stent thrombogenicity early in high-risk interventional settings is driven by stent design and deployment and protected by polymer-drug coatings. Circulation 2011;123:1400-9.

110 Basalus MW, Ankone MJ, van Houwelingen GK, de Man FH, von Birgelen C. Coating irregularities of durable polymer-based drug-eluting stents as assessed by scanning electron microscopy. Eurolntervention 2009;5:157-65.

111 Basalus MWZ, Tandjung K, Sen H, van Apeldoorn AA, Grijpma DW, von Birgelen C. Recent insights from scanning electron microscopic assessment of durable polymer-coated drug-eluting stents. Interventional Cardiology 2012;6:661-674.

112 Applegate R, Hermiller J, Williams J, Gordon P, Doostzadeh J, Cao S, et al. Evaluation of the effects of everolimus-eluting and paclitaxel-eluting stents on target lesions with jailed side branches: 2-year results from the SPIRIT III randomized trial. Catheter Cardiovasc Interv 2010;76:644-51.

113 Joner M, Nakazawa G, Finn AV, Quee SC, Coleman L, Acampado E, et al. Endothelial cell recovery between comparator polymer-based drug-eluting stents. J Am Coll Cardiol 2008;52:333-42.

114 Nakatani S, Nishino M, Taniike M, Makino N, Kato H, Egami Y, et al. Initial findings of impact of strut width on stent coverage and apposition of sirolimus-eluting stents assessed by optical coherence tomography. Catheter Cardiovasc Interv 2013;81:776-81.

115 Vicenzi MN, Meislitzer T, Heitzinger B, Halaj M, Fleisher LA, Metzler H. Coronary artery stenting and non-cardiac surgery-a prospective outcome study. Br J Anaesth 2006;96:686-93

116 Kedhi E, Stone GW, Kereiakes DJ, Serruys PW, Parise H, Fahy M, et al. Stent thrombosis: insights on outcomes, predictors and impact of dual antiplatelet therapy interruption from the SPIRIT II, SPIRIT III, SPIRIT IV and COMPARE trials. Eurolntervention 2012;8:599-606.

117 Kirtane AJ, Silber S, Neumann FJ, Serruys PW, Mauri L, Meredith IT, et al. The relation between short and long-term antiplatelet use and stent thrombosis following percutaneous coronary intervention with the Resolute zotarolimus-eluting stent. J Am Coll Cardiol 2013;61(10S):E1862.

118 Hausleiter J, Kastrati A, Mehilli J, Schuhlen H, Pache J, Dotzer F, et al. Impact of lesion complexity on the capacity of a trial to detect differences in stent performance: results from the ISAR-STEREO trial. Am Heart $J$ 2003;146:882-6.

119 Navarese EP, Kubica J, Castriota F, Gibson CM, De Luca G, Buffon A, et al. Safety and efficacy of biodegradable vs. durable polymer drug-eluting stents: evidence from a meta-analysis of randomised trials. EuroIntervention 2011;7:985-94.

120 Nakazawa G, Finn AV, John MC, Kolodgie FD, Virmani R. The significance of preclinical evaluation of sirolimus-, paclitaxel-, and zotarolimus-eluting stents. Am J Cardiol 2007;100:36-44M.

121 Task Force on Myocardial Revascularization of the European Society of Cardiology (ESC) and the European Association for Cardio-Thoracic Surgery (EACTS), European Association for Percutaneous Cardiovascular Interventions (EAPCl), Wijns W, Kolh P, Danchin N, Di Mario C, et al. Guidelines on myocardial revascularization. Eur Heart J 2010;31:2501-55.

\section{Accepted: 08 October 2013}

\section{Cite this as: BMJ 2013;347:f6530}

This is an Open Access article distributed in accordance with the Creative Commons Attribution Non Commercial (CC BY-NC 3.0) license, which permits others to distribute, remix, adapt, build upon this work non-commercially, and license their derivative works on different terms, provided the original work is properly cited and the use is non-commercial. See: http://creativecommons.org/licenses/by-nc/3.0/. 


\section{Tables}

Table 1 Randomised controlled trials included in network meta-analysis of safety and efficacy outcomes of first and second generation durable polymer drug eluting stents and biodegradable polymer biolimus eluting stents

\begin{tabular}{|c|c|c|c|c|c|}
\hline Trial & $\begin{array}{l}\text { Total sample } \\
\text { size }\end{array}$ & Stent comparators & Trial design & $\begin{array}{l}\text { Maximum } \\
\text { follow-up } \\
\text { (months) }\end{array}$ & Clinical setting (\%) \\
\hline BASKET, $2005^{16}$ & $525(826)$ & SES $v$ PES ( $v$ BMS) & $\begin{array}{l}\text { Superiority (cost } \\
\text { effectiveness)/single centre }\end{array}$ & 6 & $\begin{array}{l}\text { Stable coronary artery disease/ACS } \\
(42 / 58)\end{array}$ \\
\hline BASKET-PROVE, $2010^{17}$ & $1549(2314)$ & EES $v$ SES ( $v$ BMS) & $\begin{array}{l}\text { Superiority (cost } \\
\text { effectiveness)/multicentre }\end{array}$ & 24 & $\begin{array}{l}\text { Stable coronary artery disease/ACS } \\
(35 / 65)\end{array}$ \\
\hline CATOS, $2012^{18}$ & 160 & ZES-E $v$ SES & Parallel/multicentre & 12 & Stable coronary artery disease \\
\hline CIBELES, $2013^{19}$ & 207 & EES $v$ SES & Non-inferiority/multicentre & 12 & Stable coronary artery disease \\
\hline COMPARE, $2010-11^{2021}$ & 1800 & EES $v$ PES & Superiority/single centre & 24 & $\begin{array}{l}\text { Stable coronary artery disease/ACS } \\
(40 / 60)\end{array}$ \\
\hline COMPARE II, $2013^{9}$ & 2707 & BP-BES $v$ EES & Non-inferiority/multicentre & 12 & $\begin{array}{l}\text { Stable coronary artery disease/ACS } \\
(42 / 58)\end{array}$ \\
\hline CORPAL, $2005^{22}$ & 515 & SES $v$ PES & Parallel/multicentre & 6 & Stable coronary artery disease \\
\hline CREST MI, $2011^{23}$ & 875 & ZES-E $v$ SES & Parallel/multicentre & 6 & STEMI \\
\hline DES-diabetes, $2008-11^{24} 25$ & 400 & SES $v$ PES & Superiority/multicentre & 48 & $\begin{array}{l}\text { Stable coronary artery disease/ACS } \\
(42 / 58)\end{array}$ \\
\hline DiabeDES, $2009^{26}$ & 153 & SES $v$ PES & Superiority/multicentre & 8 & $\begin{array}{l}\text { Stable coronary artery disease/ACS } \\
(67 / 33)\end{array}$ \\
\hline ENDEAVOR III, 2006-11 2728 & 436 & ZES-E $v$ SES & Non-inferiority/multicentre & 60 & Stable coronary artery disease \\
\hline ENDEAVOR IV, 2010-13 2930 & 1548 & ZES-E $v$ PES & Non-inferiority/multicentre & 60 & $\begin{array}{l}\text { Stable coronary artery disease/ACS } \\
(53 / 47)\end{array}$ \\
\hline ESSENCE-Diabetes, $2011^{31}$ & 300 & EES $v$ SES & Non-inferiority/multicentre & 12 & $\begin{array}{l}\text { Stable coronary artery disease/ACS } \\
(58 / 42)\end{array}$ \\
\hline EXCELLENT, $2010^{32}$ & 1443 & EES $v$ SES & Non-inferiority/multicentre & 12 & $\begin{array}{l}\text { Stable coronary artery disease/ACS } \\
(48 / 52)\end{array}$ \\
\hline Hong et al, $2010^{33}$ & 169 & SES $v$ PES & Parallel/multicentre & 36 & $\begin{array}{l}\text { Stable coronary artery disease/ACS } \\
(39 / 61)\end{array}$ \\
\hline ISAR-DIABETES, $2005^{34}$ & 250 & SES $v$ PES & Non-inferiority/multicentre & 9 & $\begin{array}{l}\text { Stable coronary artery disease/ACS } \\
(60 / 40)\end{array}$ \\
\hline ISAR-Left-Main, $2009^{35}$ & 607 & SES $v$ PES & Non-inferiority/multicentre & 24 & Stable coronary artery disease \\
\hline ISAR-Left-Main 2, $2012^{36}$ & 650 & ZES-R $v$ EES & Non-inferiority/multicentre & 12 & $\begin{array}{l}\text { Stable coronary artery disease/ACS } \\
(64 / 36)\end{array}$ \\
\hline ISAR-SMART $3,2006^{37}$ & 360 & SES $v$ PES & Non-inferiority/multicentre & 12 & $\begin{array}{l}\text { Stable coronary artery disease/ACS } \\
(69 / 31)\end{array}$ \\
\hline ISAR-TEST-2, 2009-10 & $674(1007)$ & $\begin{array}{l}\text { ZES-E } v \text { SES ( } v \text { polymer } \\
\text { free dual DES) }\end{array}$ & Superiority/multicentre & 24 & $\begin{array}{l}\text { Stable coronary artery disease/ACS } \\
(58 / 42)\end{array}$ \\
\hline Juwana et al, $2009^{40}$ & 397 & SES $v$ PES & Superiority/single centre & 12 & STEMI \\
\hline Kamoi et al, $2011^{41}$ & 100 & SES $v$ PES & Parallel/single centre & 12 & Stable coronary artery disease \\
\hline Kim et al, $2008^{42}$ & 169 & SES $v$ PES & Superiority/multicentre & 6 & $\begin{array}{l}\text { Stable coronary artery disease/ACS } \\
(39 / 61)\end{array}$ \\
\hline KOMER, $2011^{43}$ & 611 & ZES-E $v$ SES $v$ PES & Parallel/multicentre & 18 & STEMI \\
\hline LEADERS, 2008-13 ${ }^{744}$ & 1707 & BP-BES $v$ SES & Non-inferiority/multicentre & 60 & $\begin{array}{l}\text { Stable coronary artery disease/ACS } \\
(45 / 55)\end{array}$ \\
\hline Long DES II, $2006^{45}$ & 500 & SES $v$ PES & Superiority/multicentre & 9 & $\begin{array}{l}\text { Stable coronary artery disease/ACS } \\
(45 / 55)\end{array}$ \\
\hline LONG-DES III, $2011^{46}$ & 450 & EES $v$ SES & Non-inferiority/multicentre & 12 & $\begin{array}{l}\text { Stable coronary artery disease/ACS } \\
(58 / 42)\end{array}$ \\
\hline LONG-DES V, $2012^{47}$ & 500 & ZES-R $v$ SES & Non-inferiority/multicentre & 12 & $\begin{array}{l}\text { Stable coronary artery disease/ACS } \\
(64 / 36)\end{array}$ \\
\hline Naples diabetes, $2010^{48}$ & 226 & ZES-E $v$ SES $v$ PES & Superiority single-centre & 36 & $\begin{array}{l}\text { Stable coronary artery disease/ACS } \\
(86 / 14)\end{array}$ \\
\hline
\end{tabular}


(continued)

\begin{tabular}{|c|c|c|c|c|c|}
\hline Trial & $\begin{array}{l}\text { Total sample } \\
\quad \text { size }\end{array}$ & Stent comparators & Trial design & $\begin{array}{l}\text { Maximum } \\
\text { follow-up } \\
\text { (months) }\end{array}$ & Clinical setting (\%) \\
\hline NEXT, $2013^{10}$ & 3235 & BP-BES $v$ EES & Non-inferiority/multicentre & 12 & $\begin{array}{l}\text { Stable coronary artery disease/ACS } \\
(84 / 16)\end{array}$ \\
\hline NOBORI 1-Phase 1, $2007^{49}$ & 120 & BP-BES $v$ PES & Non-inferiority/multicentre & 9 & $\begin{array}{l}\text { Stable coronary artery disease/ACS } \\
(80 / 20)\end{array}$ \\
\hline NOBORI 1-Phase 2, $2009^{50}$ & 243 & BP-BES $v$ PES & Non-inferiority/multicentre & 12 & $\begin{array}{l}\text { Stable coronary artery disease/ACS } \\
(72 / 28)\end{array}$ \\
\hline NOBORI Japan, $2012^{5152}$ & 335 & BP-BES $v$ SES & Non-inferiority/multicentre & 36 & $\begin{array}{l}\text { Stable coronary artery disease/ACS } \\
(86 / 14)\end{array}$ \\
\hline Pan et al, $2007^{53}$ & 205 & SES $v$ PES & Superiority/multicentre & 24 & $\begin{array}{l}\text { Stable coronary artery disease/ACS } \\
(40 / 60)\end{array}$ \\
\hline PASEO, $2009^{54}$ & $180(270)$ & SES $v$ PES ( $v$ BMS) & Superiority/single centre & 48 & STEMI \\
\hline Petronio et al, $2007^{55}$ & 100 & SES $v$ PES & Superiority/single centre & 9 & $\begin{array}{l}\text { Stable coronary artery disease/ACS } \\
(52 / 48)\end{array}$ \\
\hline PRISON III, $2013^{56}$ & 304 & $\begin{array}{l}\text { SES } v \text { ZES-E + SES } v \\
\text { ZES-R }\end{array}$ & Superiority/multicentre & 12 & Stable coronary artery disease \\
\hline PROSIT, 2008-11 $1^{5758}$ & 308 & SES $v$ PES & Superiority/multicentre & 36 & STEMI \\
\hline PROTECT, $2012^{59}$ & 8709 & ZES-E $v$ SES & Superiority/multicentre & 36 & $\begin{array}{l}\text { Stable coronary artery disease/ACS } \\
(55 / 45)\end{array}$ \\
\hline R-CHINA RCT, $2013^{60}$ & 400 & ZES-R $v$ PES & Non-inferiority/multicentre & 12 & $\begin{array}{l}\text { Stable coronary artery disease/ACS } \\
(9 / 91)\end{array}$ \\
\hline REALITY, $2006^{61}$ & 1386 & SES $v$ PES & Superiority/multicentre & 12 & $\begin{array}{l}\text { Stable coronary artery disease/ACS } \\
(70 / 30)\end{array}$ \\
\hline RESET, $2011^{62}$ & 3197 & EES $v$ SES & Non-inferiority/multicentre & 12 & $\begin{array}{l}\text { Stable coronary artery disease/ACS } \\
(82 / 18)\end{array}$ \\
\hline Separham et al, $2011^{66}$ & 200 & BP-BES $v$ EES & Parallel/single centre & 12 & $\begin{array}{l}\text { Stable coronary artery disease/ACS } \\
(29 / 71)\end{array}$ \\
\hline SIRTAX, 2005-1 $1^{6768}$ & 1012 & SES $v$ PES & Superiority/multicentre & 60 & $\begin{array}{l}\text { Stable coronary artery disease/ACS } \\
(49 / 51)\end{array}$ \\
\hline SORT OUT II, $2008^{69}$ & 2098 & SES $v$ PES & Superiority/multicentre & 18 & $\begin{array}{l}\text { Stable coronary artery disease/ACS } \\
(45 / 55)\end{array}$ \\
\hline SORT OUT III, 2010-12 $2^{7071}$ & 2332 & ZES-E $v$ SES & Superiority/multicentre & 36 & $\begin{array}{l}\text { Stable coronary artery disease/ACS } \\
(55 / 45)\end{array}$ \\
\hline SORT OUT IV, $2012^{7273}$ & 2774 & EES $v$ SES & Non-inferiority/multicentre & 24 & $\begin{array}{l}\text { Stable coronary artery disease/ACS } \\
(58 / 42)\end{array}$ \\
\hline SORT OUT V, $2013^{8}$ & 2468 & BP-BES $v$ SES & Non-inferiority/multicentre & 9 & $\begin{array}{l}\text { Stable coronary artery disease/ACS } \\
(51: 49)\end{array}$ \\
\hline SPIRIT II, 2006-12 $2^{7475}$ & 300 & EES $v$ PES & Non-inferiority/multicentre & 60 & $\begin{array}{l}\text { Stable coronary artery disease/ACS } \\
(62 / 38)\end{array}$ \\
\hline SPIRIT III, 2008-11 & 1001 & EES $v$ PES & Non-inferiority/multicentre & 36 & $\begin{array}{l}\text { Stable coronary artery disease/ACS } \\
(80 / 20)\end{array}$ \\
\hline SPIRIT IV, 2010-11 & 3717 & EES $v$ PES & Superiority/multicentre & 24 & $\begin{array}{l}\text { Stable coronary artery disease/ACS } \\
(72 / 28)\end{array}$ \\
\hline SPIRIT V, $2012^{80}$ & 324 & EES $v$ PES & Non-inferiority/multicentre & 12 & $\begin{array}{l}\text { Stable coronary artery disease/ACS } \\
(64 / 36)\end{array}$ \\
\hline TAXI-LATE, 2005-0 $07^{8182}$ & 202 & SES $v$ PES & Superiority/single centre & 36 & $\begin{array}{l}\text { Stable coronary artery disease/ACS } \\
(84 / 16)\end{array}$ \\
\hline TWENTE, 2012-13 $13^{8384}$ & 1391 & ZES-R $v$ EES & Non-inferiority/single centre & 24 & $\begin{array}{l}\text { Stable coronary artery disease/ACS } \\
(49 / 51)\end{array}$ \\
\hline XAMI, $2012^{85}$ & 625 & EES $v$ SES & Non-inferiority/multicentre & 12 & STEMI \\
\hline ZEST, $2010^{86}$ & 2645 & ZES-E $v$ SES $v$ PES & $\begin{array}{l}\text { Superiority (ZES-E } v \\
\text { PES)/non-inferiority (ZES-E } v \\
\text { SES)/multicentre }\end{array}$ & 12 & $\begin{array}{l}\text { Stable coronary artery disease/ACS } \\
(45 / 55)\end{array}$ \\
\hline ZEST-AMI, $2009^{87}$ & 328 & ZES-E $v$ SES $v$ PES & Superiority/multicentre & 12 & STEMI \\
\hline Zhang et al, $2006^{88}$ & 673 & SES $v$ PES & Superiority/single centre & 12 & $\begin{array}{l}\text { Stable coronary artery disease/ACS } \\
(45 / 55)\end{array}$ \\
\hline
\end{tabular}


(continued)

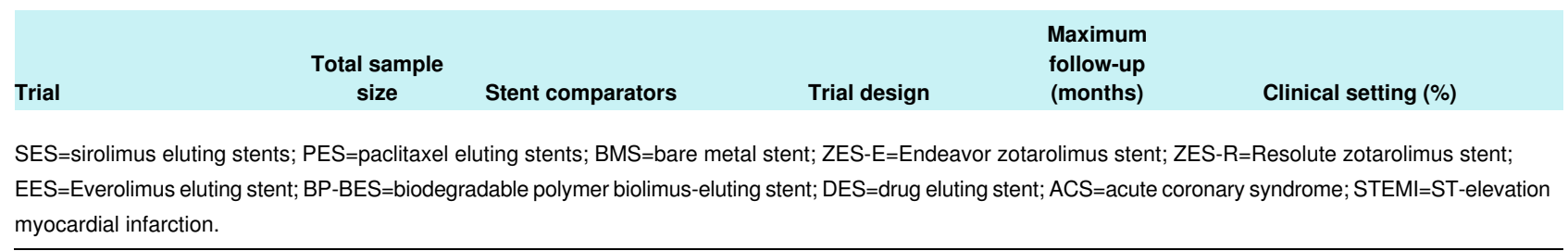


Table 2| One year event rates with different types of drug eluting stent (DES). Numbers are rates (95\% credible intervals)

\begin{tabular}{|c|c|c|c|c|c|c|}
\hline & SES & PES & EES & ZES-E & BP-BES & ZES-R \\
\hline Death & 2.45 (1.86 to 3.14$)$ & 2.68 (1.88 to 3.75$)$ & 2.27 (1.59 to 3.17 ) & 3.05 (1.96 to 4.62 ) & 2.48 (1.64 to 3.67 ) & $1.80(1.04$ to 3.00$)$ \\
\hline $\begin{array}{l}\text { Myocardial } \\
\text { infarction }\end{array}$ & 2.58 (1.98 to 3.30$)$ & 3.44 (2.53 to 4.61$)$ & 2.32 (1.68 to 3.16$)$ & 2.47 (1.67 to 3.58$)$ & 3.00 (2.07 to 4.27$)$ & 2.28 (1.52 to 3.39$)$ \\
\hline Stent thrombosis & $1.42(0.98$ to 1.96$)$ & 2.38 (1.27 to 4.30$)$ & $0.89(0.44$ to 1.66$)$ & 2.74 (1.01 to 6.91$)$ & 1.38 (0.57 to 3.03$)$ & $1.11(0.33$ to 3.01$)$ \\
\hline \multicolumn{7}{|c|}{ Target revascularisation: } \\
\hline Lesion & 3.25 (2.57 to 4.04$)$ & $5.92(4.30$ to 8.05$)$ & 3.03 (2.06 to 4.40$)$ & 7.52 (4.97 to 11.29$)$ & 3.18 (1.95 to 4.97$)$ & $3.25(1.77$ to 5.71$)$ \\
\hline Vessel & 4.91 (4.07 to 5.86$)$ & 7.05 (5.21 to 9.41$)$ & 4.30 (3.11 to 5.87$)$ & 7.93 (5.11 to 12.19$)$ & 4.93 (3.27 to 7.43$)$ & 4.59 (2.45 to 8.36$)$ \\
\hline
\end{tabular}

SES=sirolimus eluting stent; PES=paclitaxel eluting stent; EES=everolimus eluting stent; ZES-E=Endeavor zotarolimus eluting stent; BP-BES=biodegradable polymer biolimus eluting stent; ZES-R=Resolute zotarolimus eluting stent. 


\section{Figures}

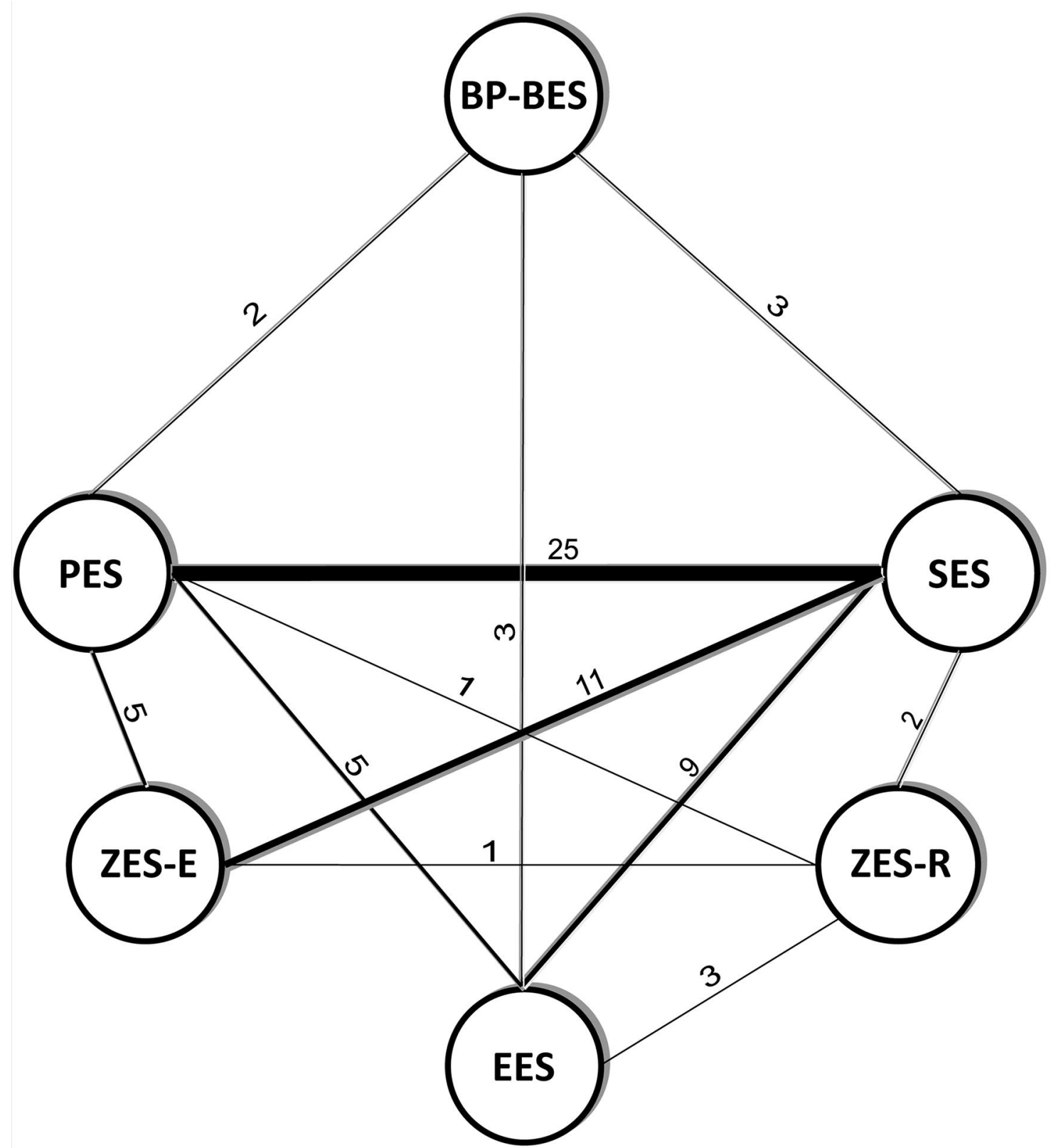

Fig 1 Evidence network among stents included in meta-analysis. Links between stent types represent direct (lines) comparison studies. Nodes denote stent type; thickness of link indicates number of direct comparisons. SES=sirolimus eluting stent; $P E S=$ paclitaxel eluting stent; $E E S=$ =verolimus eluting stent; ZES-E=Endeavor zotarolimus eluting stent; BP-BES=biodegradable polymer biolimus eluting stent; ZES-R=Resolute zotarolimus eluting stent 


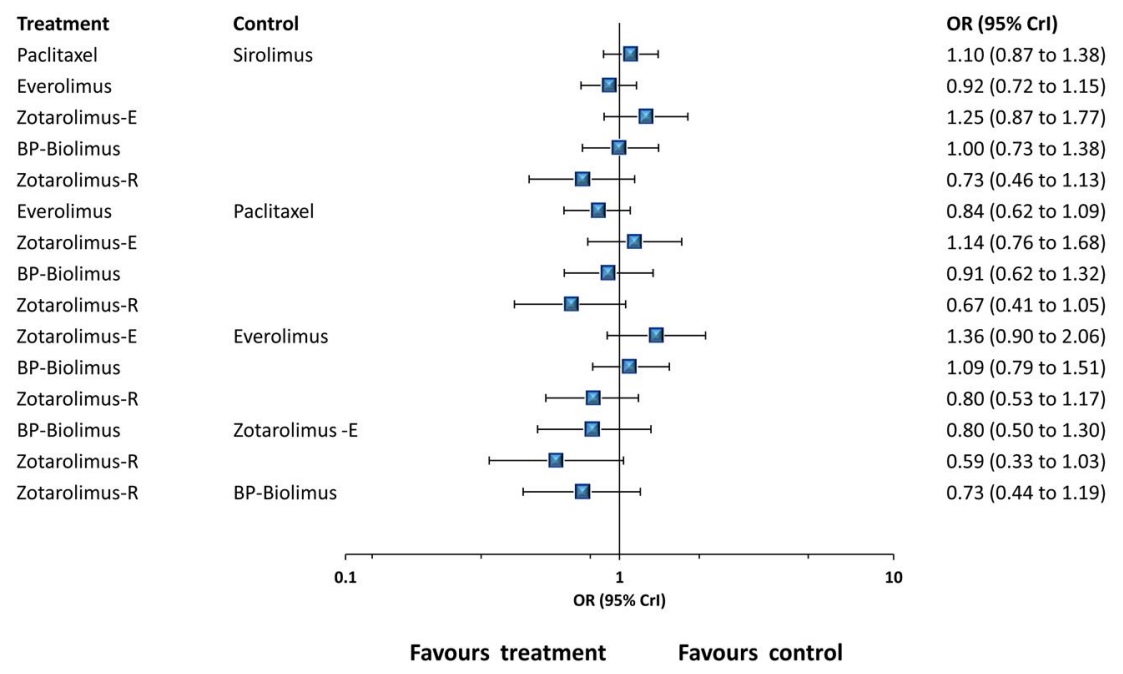

Fig 2 Pooled odds ratio and 95\% credible intervals determined by network meta-analysis for mortality. BP=biodegradable polymer; E=Endeavor; R=Resolute

\begin{tabular}{|c|c|c|c|}
\hline Treatment & Control & & OR (95\% Crl) \\
\hline Paclitaxel & Sirolimus & $\vdash$ 回- & 1.34 (1.14 to 1.59 ) \\
\hline Everolimus & & $\vdash$ 田 & 0.90 (0.74 to 1.08 ) \\
\hline Zotarolimus-E & & 上回— & 0.96 (0.71 to 1.26$)$ \\
\hline BP-Biolimus & & 一回一 & 1.16 (0.89 to 1.52 ) \\
\hline Zotarolimus- $R$ & & 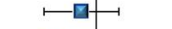 & 0.88 (0.64 to 1.21 ) \\
\hline Everolimus & Paclitaxel & $\vdash$ 回- & 0.67 (0.53 to 0.81$)$ \\
\hline Zotarolimus-E & & 一回一 & 0.71 (0.52 to 0.94$)$ \\
\hline BP-Biolimus & & 一回十 & 0.87 (0.64 to 1.15 ) \\
\hline Zotarolimus- $\mathrm{R}$ & & $\longmapsto \square \longrightarrow$ & 0.66 (0.46 to 0.91$)$ \\
\hline Zotarolimus-E & Everolimus & $\longmapsto \square-$ & 1.07 (0.75 to 1.47$)$ \\
\hline BP-Biolimus & & 一回一 & 1.29 (1.02 to 1.69$)$ \\
\hline Zotarolimus-R & & $\longrightarrow$ & 0.98 (0.73 to 1.32$)$ \\
\hline BP-Biolimus & Zotarolimus -E & $-\square \longrightarrow$ & 1.21 (0.83 to 1.79$)$ \\
\hline Zotarolimus- $R$ & & $\longmapsto \square$ & 0.92 (0.60 to 1.40$)$ \\
\hline \multirow[t]{2}{*}{ Zotarolimus-R } & BP-Biolimus & —回一 & 0.76 (0.51 to 1.11$)$ \\
\hline & 0.1 & OR ( $95 \% \mathrm{Crl})$ & \\
\hline
\end{tabular}

Fig 3 Pooled odds ratio and 95\% credible intervals determined by network meta-analysis for myocardial infarction. $\mathrm{BP}=$ biodegradable polymer; $\mathrm{E}=$ Endeavor; $\mathrm{R}=$ Resolute

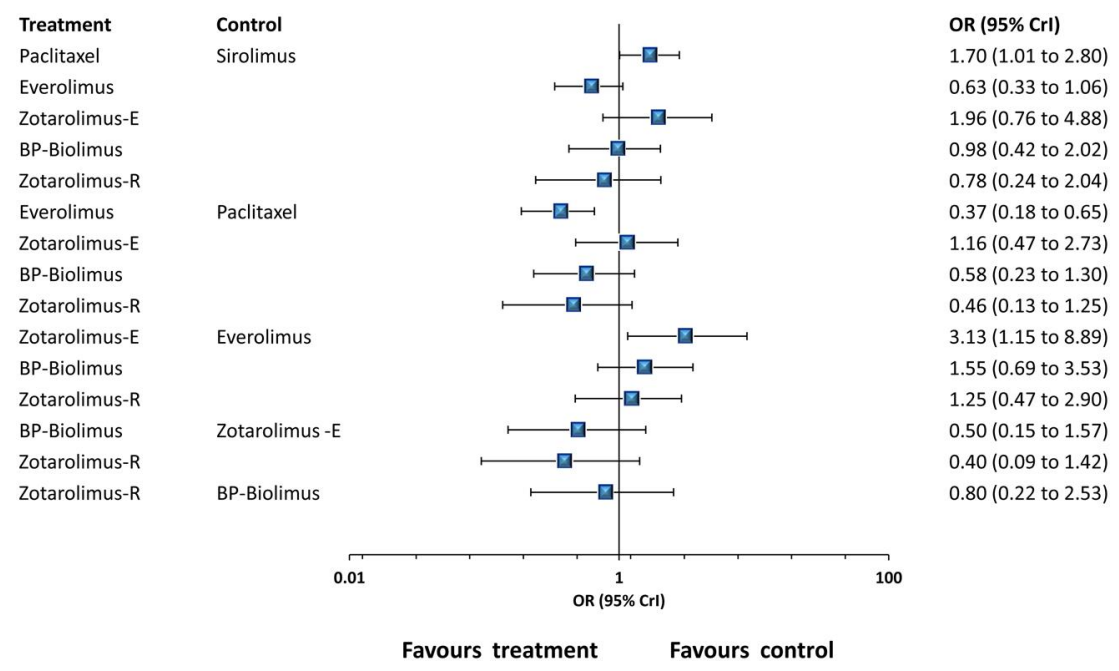

Fig 4 Pooled odds ratio and 95\% credible intervals determined by network meta-analysis for definite or probable stent thrombosis. $\mathrm{BP}=$ biodegradable polymer; $\mathrm{E}=$ Endeavor; $\mathrm{R}=$ Resolute 


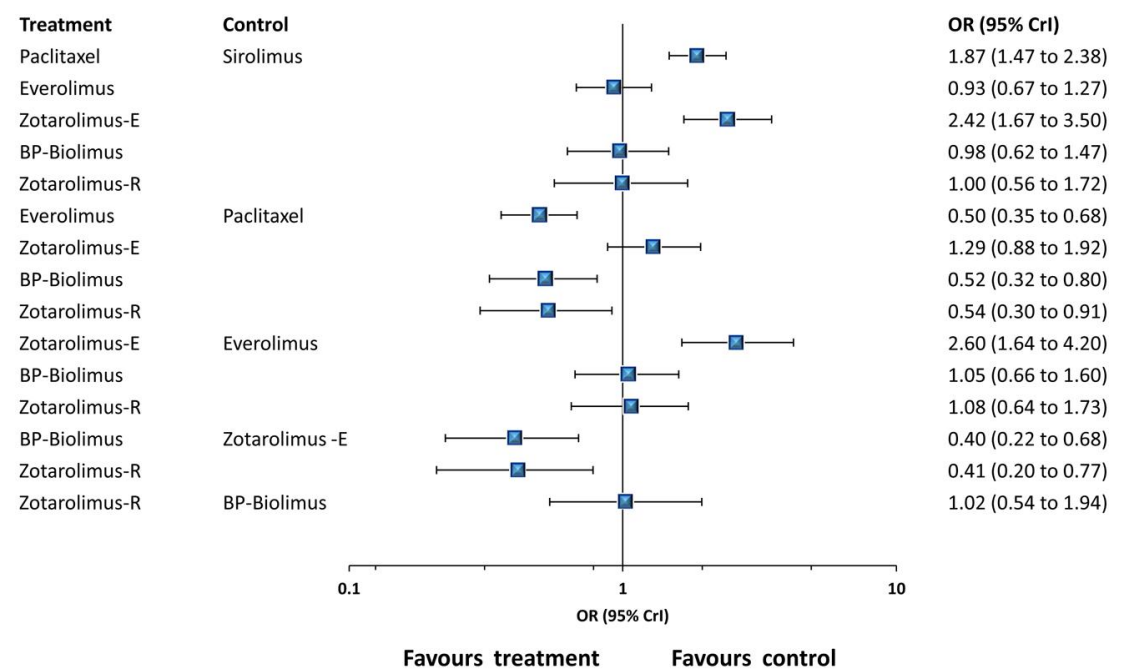

Fig 5 Pooled odds ratio and 95\% credible intervals determined by network meta-analysis for target lesion revascularisation. $\mathrm{BP}=$ biodegradable polymer; $\mathrm{E}=$ Endeavor; $\mathrm{R}=$ Resolute

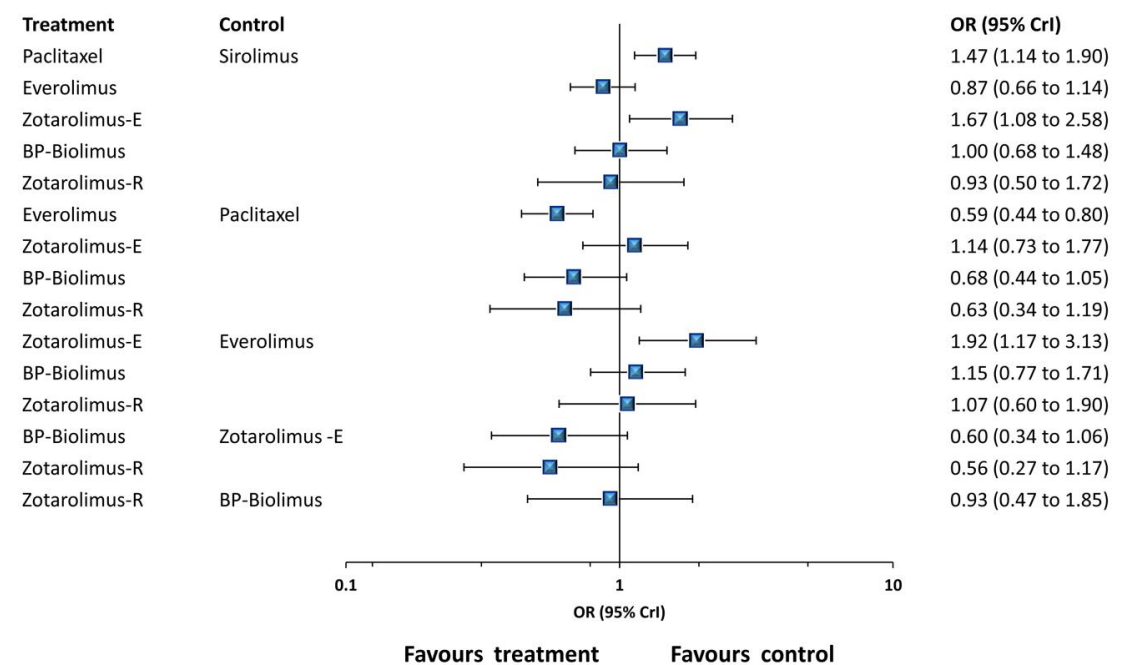

Fig 6 Pooled odds ratio and 95\% credible intervals determined by network meta-analysis for target vessel revascularisation. $\mathrm{BP}=$ =biodegradable polymer; $\mathrm{E}=$ Endeavor; $\mathrm{R}=$ Resolute 

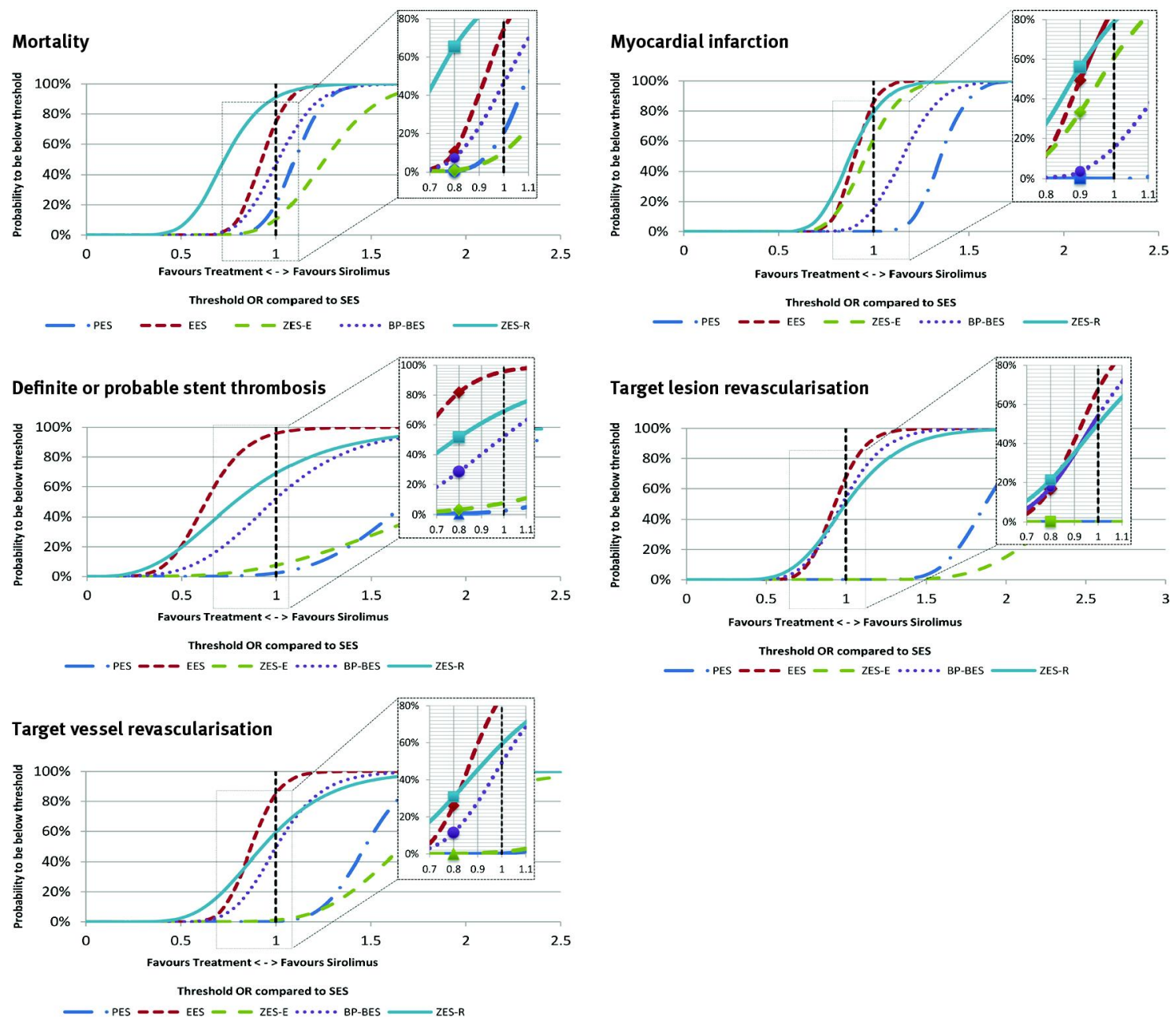

Fig 7 Posterior probabilities of different risk thresholds (odds ratios) for each stent compared with sirolimus eluting stent (reference treatment). Curves can be used to examine overall safety and efficacy profile of specific DES compared with reference treatment sirolimus-ES (SES) (identity line=unit value); improved safety and efficacy profiles indicated by highest leftward shift of curve, as shown with Resolute zotarolimus-ES (ZES-R) and everolimus-ES (EES) with regard to mortality and myocardial infarction; curves allow inferences to extract probabilities of specific risk thresholds corresponding to minimal odds ratio compared with sirolimus-ES as reference treatment. For example, compared with sirolimus-ES, there is probability of $65 \%$ that Resolute zotarolimus-ES reduce odds of mortality by at least $20 \%$ corresponding to odds ratio of 0.80 ; conversely, this probability is estimated to be close to $0 \%$ with biodegradable polymer biolimus-ES (BP-BES), meaning no additional mortality benefit provided by biodegradable polymer biolimus-ES compared with sirolimus-ES; there is a probability of $56 \%$ and $49 \%$, respectively, that Resolute zotarolimus-ES and everolimus-ES reduced odds of myocardial infarction by at least $10 \%$ corresponding to odds ratio of 0.90 but this probability is estimated close to $0 \%$ with biodegradable polymer biolimus-ES, meaning no additional myocardial infarction benefits provided by biodegradable polymer biolimus-ES compared with sirolimus-ES (reference treatment). PES=paclitaxel eluting stent; ZES-E=Endeavor zotarolimus-ES 